\title{
The Evolving Role of Natural Compounds in the Medical Treatment of Uterine Fibroids
}

\author{
Michał Ciebiera ${ }^{1,2,+} \mathbb{D}$, Mohamed Ali ${ }^{2,3,+}$, Lillian Prince ${ }^{4} \mathbb{D}$, Tia Jackson-Bey ${ }^{5}$, \\ Ihor Atabiekov ${ }^{6}{ }^{D}$, Stanisław Zgliczyński ${ }^{7}$ and Ayman Al-Hendy ${ }^{2, *}$ \\ 1 Second Department of Obstetrics and Gynecology, The Center of Postgraduate Medical Education, \\ 01-809 Warsaw, Poland; michal.ciebiera@gmail.com \\ 2 Department of Surgery, University of Illinois at Chicago, Chicago, IL 60612, USA;mali78@uic.edu \\ 3 Clinical Pharmacy Department, Faculty of Pharmacy, Ain Shams University, 11566 Cairo, Egypt \\ 4 School of Public Health, University of Illinois at Chicago, Chicago, IL 60612, USA; lprinc4@uic.edu \\ 5 Division of Reproductive Endocrinology and Infertility, Department of Obstetrics and Gynecology, \\ University of Illinois at Chicago, Chicago, IL 60612, USA; tjacks36@uic.edu \\ 6 Moscow Region Cancer Center, Balashikha 143900, Russian; i.atabiekov@gmail.com \\ 7 Department of Internal Diseases and Endocrinology, Central Teaching Clinical Hospital, \\ Medical University of Warsaw, 02-097 Warsaw, Poland; stanislaw.zgliczynski@gmail.com \\ * Correspondence: aalhendy@uic.edu; Tel.: +1-312-996-7006 \\ + These authors contributed equally to this work.
}

Received: 21 April 2020; Accepted: 11 May 2020; Published: 14 May 2020

\begin{abstract}
Uterine fibroids (UFs) remain a significant health issue for many women, with a disproportionate impact on women of color, likely due to both genetic and environmental factors. The prevalence of UFs is estimated to be approximately $70 \%$ depending on population. UF-derived clinical symptoms include pelvic pain, excessive uterine bleeding, gastrointestinal and voiding problems, as well as impaired fertility. Nowadays numerous methods of UF treatment are available-from conservative treatment to invasive surgeries. Selecting an appropriate treatment option should be individualized and adjusted to the patient's expectations as much as possible. So far, the mainstay of treatment is surgery, but their negative impact of future fertility is clear. On the other hand, emerging new pharmaceutical options have significant adverse effects like liver function impairment, hot flashes, bone density loss, endometrial changes, and inability to attempt conception during treatment. Several natural compounds are found to help treat UFs and relieve their symptoms. In this review we summarize all the current available data about natural compounds that may be beneficial for patients with UFs, especially those who want to preserve their future fertility or have treatment while actively pursuing conception. Vitamin D, epigallocatechin gallate, berberine, curcumin, and others are being used as alternative UF treatments. Moreover, we propose the concept of using combined therapies of natural compounds on their own or combined with hormonal agents to manage UFs. There is a strong need for more human clinical trials involving these compounds before promoting widespread usage.
\end{abstract}

Keywords: uterine fibroid; leiomyoma; vitamin D; epigallocatechin gallate; natural; therapy; pharmacotherapy; phytotherapy; prevention; diet

\section{Introduction}

Uterine fibroids (UF) are the most common benign gynecological tumor in premenopausal-age women, affecting up to 70\% of women depending on the selected population [1]. In women of color this prevalence can be $80 \%$ [2]. Although considered benign, these lesions are often associated with significant morbidity. Up to $30 \%$ of afflicted patients become symptomatic with the most common 
manifestations: Abnormal uterine bleeding, pelvic pain, gastrointestinal issues, voiding problems, bulk symptoms, obstetric complications, and infertility [3]. Overall quality of life (QoL) in women with UFs is seriously impaired [4,5]. Recent studies from France found that about two thirds of surveyed women reported that UFs have a moderate to high impact on their QoL, highlighting the need for medical intervention [5]. About 30\% of all hysterectomies among women of reproductive age are due to UFs [6]. Moreover, UFs are the most common indication for hysterectomy in the United States [7]. Surgical treatment choice for UFs imparts a substantial financial burden [8]. Cardozo et al reported that total annual cost of UFs in the United States, including direct and indirect costs, was estimated from $\$ 5.9$ to $\$ 34.4$ billion [9]. These data fully emphasize the growing awareness of the significant economic impact of UFs and urge the search for efficient alternative treatment as well as preventive options [10]. Observations made over the past years showed an increase in the number of women who wish to preserve their uteri for different reasons [7].

The careful selection of treatment modality should be made based on numerous criteria. Surgery remains the method of choice with the best cure rates; however, we can see a big move to minimally-invasive techniques through recent years. There is also an ongoing search to find efficient, cost effective, and safe anti-UFs drugs [7,11]. Recently, safety concerns have been raised for some drugs already available or under investigation [12]. Therefore, there is urgent need for alternatives to both prevent and treat UFs [13].

\subsection{Uterine Fibroid Pathogenesis-Overview}

Since the mechanisms underlying UFs pathogenesis have not been fully elucidated, numerous studies were and are still conducted in this regard. These mechanisms affect multiple levels of cellular and tissue function. Current UF origin theory believes that it is a mix of early life exposure (e.g., environmental) and estrogen hyper-responsiveness [14] with some additional factors that cause immunological changes [15] which result in impaired DNA repair leading to cell mutations [16]. Since 2011, with the presentations of results by Mäkinen et al. [17], most studies on UFs have focused on specific somatic mutations in the MED12 gene encoding the mediator complex subunit 12 (MED12) [17,18]. According to available data, this mutation has been confirmed in more than $70 \%$ of patients with UF, depending on the population $[17,19]$. The UF life cycle might be divided into two steps: Transformation and tumor formation $[18,20]$. The transformation of normal myometrial stem cells into abnormal ones occur mostly through mentioned mutations. Myometrial stem cells transform into pathological ones and grow into uterine lesions mostly under the influence of hormones, and the growth of the tumors occurs through massive cell expansion and extracellular matrix (ECM) accumulation [21,22]. The ECM found in UFs is more abundant than in the healthy myometrium. It is believed that in here, the ECM volume may be over twice the volume of that found in the healthy myometrium. Various types of collagen, fibronectin, and proteoglycans are the main components of ECM [21,22]. Different fibers forming ECM found in UFs have an abnormal structure and differ from their counterparts in unchanged tissues [23].

Notably, ovarian sex hormones play a significant role in UF pathophysiology $[18,24,25]$. Recent data suggests that estrogen is important, but progesterone now is considered the key hormone initiating pathological differentiation and growth [18] and involves different pathways and growth factors [22,26]. Estrogen regulates transcription of proto-oncogenes and growth factor genes by binding to the nuclear estrogen receptor (ER)- $\alpha[27,28]$. Andersen et al. found UF cells to be more responsive to $17 \beta$-estradiol than normal myometrial cells [29]. Dysregulation of steroid hormone receptors may be a primary pre-requisite for UF development [30]. Dose- and time-dependent induction of proliferation in UF cell lines in response to estrogen was also found in some laboratory studies [25,31]. Moreover, adenovirus-mediated delivery of a dominant-negative estrogen receptor gene abolishes estrogen- and progesterone-regulated gene expression in UF cells in vitro and shrinks UFs tumor in vivo [32,33]. Estradiol has a permissive effect on progesterone-mediated growth of UFs. Additionally, estrogens combined with progesterone significantly increase cellular expression of proliferation marker 
Ki-67 [34] and lead to ECM accumulation due to accelerated synthesis of collagen types 1 and 3 [35]. Ishikawa et al. demonstrated that UF xenografts have a 3-fold higher volume when treated with estrogen/progesterone combination versus estradiol alone or untreated controls, highlighting the significant role of progesterone in UF growth [24].

The action of steroid hormones on abnormal cells is mediated through different mechanisms, including a paracrine manner [18]. Cytokines and growth factors are large groups of protein mediators, transmitting information between cells that are responsible for differentiation, apoptosis, cell migration, and immunological mechanisms. As per UFs, they affect the growth and survival of their cells, regulate angiogenesis, and regulate the formation of the ECM [26]. Steroid-induced cytokines and growth factors affect UF signaling. This influences UF cells to grow and survive and ECM to accumulate. ECM is also some kind of reservoir for growth factors and cytokines as it increases their stability and extends their influence [21]. Among these growth factors, different isoforms of transforming growth factor (TGF- $\beta$ ) are one of the most important [22]. Laboratory studies have demonstrated that TGF- $\beta$ reduces the concentrations of respective metalloproteinases (MMPs) and increases the concentration of their inhibitors (TIMPs) [36]. According to different studies, expression of TGF- $\beta$ is significantly increased in myometrial cells that are in direct contact with the UF tumor [37]. TGF- $\beta$ signaling is related to many pathways including Smad pathway, phosphoinositide 3-kinase (PI3K)/Akt/mammalian target of rapamycin (mTOR), the mitogen-activated protein kinases (MAPK) signaling cascade, and focal adhesion kinase (FAK) [22]. The other crucial factor in UF biology is activin A. It is produced by macrophages and it is responsible for different immunological actions including cell transformation, leading to tumor development $[15,38]$. Activin A is suggested also to be responsible for ECM production regulation [39].

Wingless-type (Wnt)/ $\beta$-catenin pathway is another important pathway in UF biology. It plays a role in somatic stem-cell function in the myometrium and in UF tissue [18]. It has been confirmed that $\beta$-catenin regulates and stimulates the renewal of stem cells [40]. According to recent studies $\beta$-catenin expression is increased in UFs compared to the adjacent myometrium samples [41]. Regulation of the biologic functions of $\beta$-catenin is highly complex. Wnt proteins bind to special cell-surface receptors, causing the activation of a cascade of proteins that leads to decreased $\beta$-catenin degradation in the cytosol which causes changes of $\beta$-catenin levels in the nucleus $[18,42]$. Ovarian steroids interact with the Wnt $/ \beta$-catenin pathway to accelerate tumorigenesis [40]. In 2013 Ono et al. demonstrated that the paracrine activation of the Wnt/ $\beta$-catenin pathway in UF stem cells promoted tumor growth [42]. It was then suggested that the canonical Wnt pathway may be a potential therapeutic target for the treatment of UFs [43]. Further research revealed that MED12 gene silencing reduced the proliferation of UF cells and it was mediated by this canonical pathway [44]. A recent study by El Andaloussi et al. [45] demonstrated that MED12 mutation presented a potential to transform cells by dysregulating Wnt $4 / \beta$-catenin which affected mTOR signaling and caused autophagy abrogation, cell proliferation, and tumorigenesis [45]. In 2020, Ali et al. also found that $\beta$-catenin nuclear translocation contributes to UF phenotype, and $\beta$-catenin signaling is modulated by estradiol and histone deacetylases activity [46]. Additionally, the Wnt/ $\beta$-catenin pathway leads to increased levels of TGF- $\beta 3[18,22]$. Some of those findings were supported with studies that used anti-UF agents which caused the attenuation of this pathway by reducing TGF- $\beta 3$ signal and protein expression, resulting in a reduction in TGF- $\beta$ canonical signaling [47]. In summary, interactions between $W n t / \beta$-catenin and TGF- $\beta$ pathways, as well as with steroids, give rise to the clonal formation of UF tumors and are believed to be basis of modern UF biology hypothesis $[18,44]$. The scheme of current UF origin theory is presented in Figure 1. 


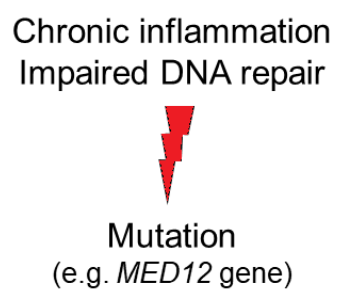

TRANSFORMATION
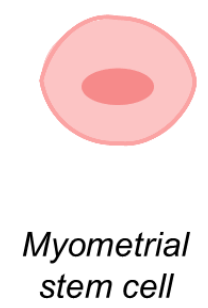

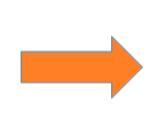
Uterine fibroid stem cell

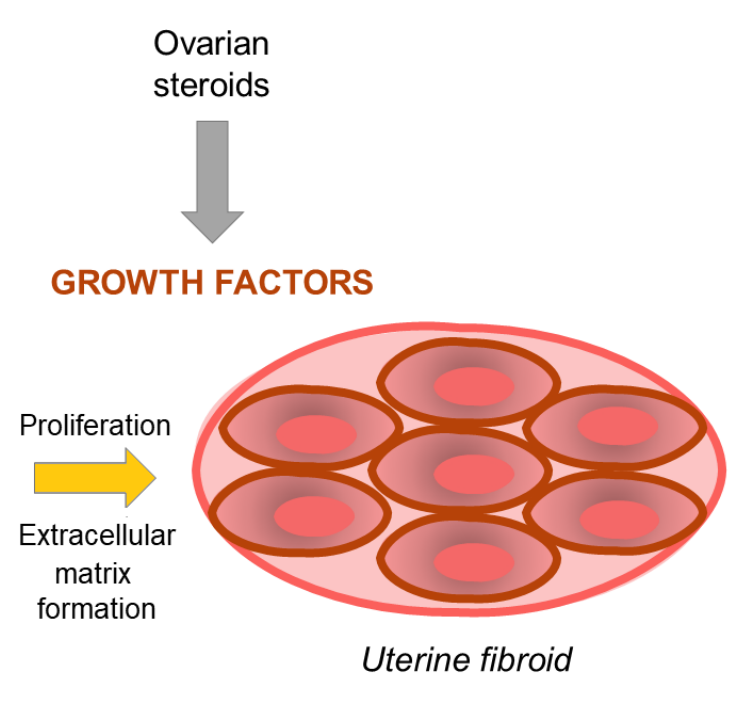

Figure 1. Development and growth of uterine fibroid — simplified scheme. Importance of mutation-derived transformation and stimulation of hormones and growth factors.

\subsection{Uterine Fibroid Treatment Challenges}

Surgical management via hysterectomy, myomectomy, uterine artery embolization (UAE), radiofrequency thermal ablation, and different types of focused ultrasound (FUS) remain as prime treatments for UFs. However, these are limited by financial burden as well as their impact on future fertility $[3,48]$. Pharmaceutical treatments have emerged like selective progesterone receptor modulators (SPRMs) and oral gonadotrophin-releasing hormone $(\mathrm{GnRH})$ antagonist [49]. Injectable $\mathrm{GnRH}$ analogs are still limited as a short-course adjunct prior to surgery to improve anemia, as these cause osteoporosis, hot flashes, headaches, and other climacteric symptoms [49]. New oral GnRH antagonists (e.g., elagolix and relugolix) were found to be effective in reducing heavy menstrual bleeding in women with UFs and have a good safety profile [50]. Ulipristal acetate (UPA), one of the famous SPRMs, was reported to be highly effective in reducing UF volume, improving QoL, and reducing UF-related symptoms [51,52]. Until recently, they were drugs of choice for women who rejected surgery or who were prepared for a subsequent surgery $[53,54]$. However, UPA was found to cause different adverse effects. For example, progesterone blockade at the level of the myometrium could induce benign endometrial changes known as progesterone associated endometrial changes (PAEC), which required drug-free intervals to resolve. Such changes limit long-term use of these therapies [55]. Recent studies found that it could also cause liver failure that may require liver transplantation $[56,57]$. Clinical trials of vilaprisan, another SPRM, showed promising results. However, it was found to be potentially toxic in long-term research on animals and therefore all current trials were halted [58].

Given this body of evidence, there are many attempts to find an inexpensive, safe, long term, fertility friendly, and effective drug for the prevention and treatment of UFs [11]. Currently, only short-term usage and relatively high costs with questionable efficacy treatment options are available for UF medical therapy. The high amount of data in the literature suggests that natural and herbal compounds showed promising results on several types of tumors, suggesting that they may become future potential options for long-term UF treatment with minimal side effects.

In this comprehensive review, we aim to summarize all published studies regarding using natural and botanical compounds against UFs in vitro, in vivo animal models, and in clinical trials. 


\section{Materials and Methods}

Authors conducted their search on PubMed of the National Library of Medicine and Google Scholar. Databases were extensively searched for all original and review articles, as well as book chapters and published abstracts using keywords (single or in combination): Uterine fibroid; uterine leiomyoma; fibrosis; natural, botanical treatment; anthocyanin; berberine; collagenase, clostridium histolyticum; curcumin; docosahexaenoic acid; eicosapentaenoic acid; epigallocatechin gallate; fucoidan; indole-3-carbinol; isoliquiritigenin; lycopene; methyl jasmonate; resveratrol; quercetin; strawberry; sulforaphane; green tea; and vitamin D published in English until April 2020. Additional articles in bibliographies of reviewed articles were also searched. In summary, most relevant articles were reviewed and included as appropriate.

\section{Discussion}

\subsection{Natural Compounds}

In this section we will discuss the available natural anti-UF compounds in details.

\subsubsection{Vitamin D}

Vitamin $\mathrm{D}$ is a common name for a group of fat-soluble steroid compounds that present pleiotropic effects on the human body with receptor found in various tissues [59]. Vitamin D fulfills all the requirements to be classified as a hormone [59]. Although it can be found in several forms, the most two described are ergocalciferol (vitamin D2 in plants) and cholecalciferol (vitamin D3-produced in the skin under the influence of sunlight) [60,61]. Studies have shown that cholecalciferol is more effective at raising serum 25 -hydroxyvitamin $\mathrm{D}[25(\mathrm{OH}) \mathrm{D}]$ in patients with vitamin $\mathrm{D}$ deficiency as compared to ergocalciferol [60].

Vitamin D supplementation is usually recommended in oral or injectable forms [62]. The active form 1,25-dihydroxyvitamin D3 [1,25(OH)D] plays a central role in calcium-phosphate balance and regulation. Activation of vitamin $\mathrm{D}$ involves several steps in the body, starting with prohormone vitamin D synthesis in the skin, secondary to sunlight exposure, then conversion to $1,25(\mathrm{OH}) \mathrm{D}$ in the liver and kidneys [63]. Dietary sources of vitamin D include fatty fish like tuna, mackerel, and salmon, beef liver, egg yolks, and foods fortified with vitamin D such as dairy products, orange juice, and breakfast cereals [59].

Women of color have much higher risk of serum vitamin D deficiency compared to white women $[18,19]$. Up to $80 \%$ of non-Hispanic African American (AA) women had vitamin D deficiency versus only $20 \%$ of white women $[64,65]$. Vitamin D deficiency is an important risk factor for UFs development process and black women are also 3-4 times more likely than white women to have UF $[3,66,67]$. Given these parallel disparities, there is current interest to understand the role of vitamin $\mathrm{D}$ in the pathogenesis of UFs. Serum vitamin D levels are lower in women with UFs versus women without UFs $[67,68]$. Sabry et al. found an increased UF incidence in vitamin D deficient women and an inverse correlation between vitamin D levels and total UF volume [67]. Similarly, Baird et al. showed that the prevalence of UFs was found to be inversely related to vitamin D levels in 35-49 years old African American and Caucasian females [69].

Vitamin D exhibited anti-proliferative, pro-apoptotic effects and induces cell differentiation in different diseases [70-72]. Vitamin D inhibits growth of UF cells through the down-regulation of kinases and Bcl2, and suppresses catechol-O-methyltransferase (COMT) expression and activity [73]. Vitamin D was tested on a rat model for UFs and a significant decrease in tumor size was observed [74]. Al-Hendy et al. demonstrated decreased estrogen-induced UF cell proliferation following vitamin D treatment [31]. Moreover, the expression of estrogen receptor (ER- $\alpha$ ) and progesterone receptors (PR-A and PR-B) was inversely correlated to vitamin D receptor (VDR) expression in UF tissue compared to normal myometrium The same group reported that estrogen treatment decreased VDR expression and up-regulated PR-A and PR-B in UF cells [31]. On the other hand, vitamin D treatment significantly 
reduced the expression of ER- $\alpha, \mathrm{PR}-\mathrm{A}, \mathrm{PR}-\mathrm{B}$, and steroid receptor co-activators (SRC) in vitro via induction of VDR expression. These effects indicate that vitamin D antagonizes sex hormones in UF cells and thus may have a role as an anti-UF treatment [31]. Similar results were showed using vitamin $\mathrm{D}$ analog paricalcitol both in vitro and in in vivo animal model of UFs [75].

The anti-fibrotic effect of vitamin D on UFs is further supported by reduction of transforming growth factor (TGF)- $\beta 3$ induced ECM proteins expression as fibronectin and collagen type 1 in UF cells, which were found to be overexpressed in UFs [76]. As an important ECM modulating compound, vitamin D inhibits MMPs and decreases ECM production in UFs lesions, which correlates to UF phenotype and its bulk symptoms [77,78]. In 2018, Elhusseini et al. showed that vitamin D deficient diet in mice triggered low serum vitamin D levels and resulted in increased expression of steroid receptors in myometrium, increased expression of proliferation related genes, and enhanced inflammation and DNA damage [16]. Recently, Corachan et al. found that treatment with vitamin D did not change UF size when it was used for a short time; however, long-term usage induced a significant tumor volume reduction due to the lower cell proliferation rate in human-xenograft animal model [79].

Limited clinical trials are available. In 2016, Ciavattini et al. found that vitamin D-treated women presented with reduced disease progression in small UFs [80]. In a controlled study by Porcaro et al. in 2020, women with symptomatic UFs were treated with vitamin D together with epigallocatechin gallate (EGCG) and vitamin B6 for 4 months. The study found that total UF volume decreased by $34.7 \%$ in the treated group but increased by $6.9 \%$ in the control group. Authors concluded that such a combination might be a new form of non-hormonal treatment for women with UFs [81]. The concept of potential synergisms was also studied in the vitamin D and UPA combination with encouraging anti-UF effects both in UF cells [82] and in patients [83]. Both studies concluded that there might be a potential synergism between UPA and vitamin D to treat UFs [82,83]. However, the recent safety concerns of UPA induced liver injury ceased advancing the studies and consequently new synergisms are still to be explored (Figure 2).

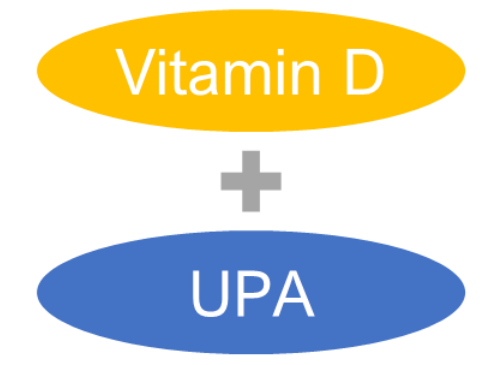

\section{Synergism proven}

UPA potential toxicity

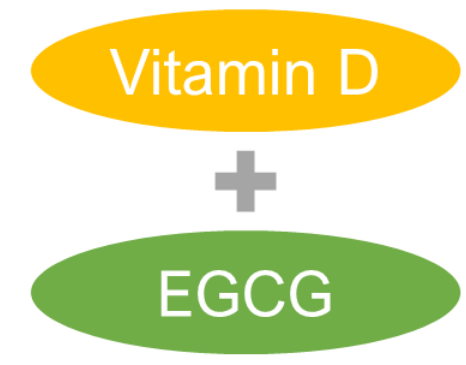

\section{Synergism proven}

Clinical trials needed

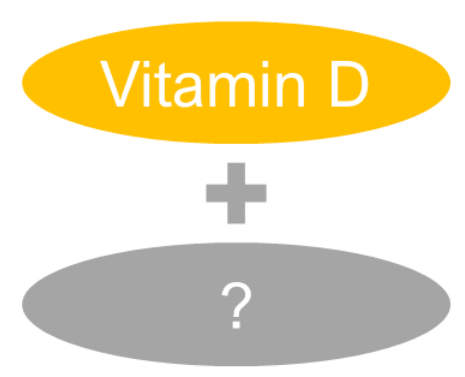

Further research needed

Figure 2. Synergistic combinations of Vitamin D in uterine fibroid (UF) therapy. EGCG: epigallocatechin gallate, UPA: ulipristal acetate.

Finally, a recent randomized controlled trial conducted in Iran by Arjeh et al. concluded that using 50,000 IU of vitamin D for 12 weeks did not change the volume of UFs but inhibited their further growth while the sizes of UFs in the placebo group increased [84].

Collectively, vitamin D has emerged as a notable candidate for UF treatment and possible prevention, considering its demonstrated anti-UFs effects along with a favorable safety profile. More human clinical trials are needed to confirm the effectiveness of vitamin $\mathrm{D}$, alone or in combinations with other natural/pharmaceutical compounds, in UFs management. 


\subsubsection{Epigallocatechin Gallate (EGCG)}

Green tea has been extensively studied for several health benefits. It is processed without fermentation, a key step in black tea production, resulting in its light color and high content of antioxidant catechin polyphenols [85,86]. There are five subtypes of these family including EGCG [87]. The single serving of green tea is estimated to contain up $150 \mathrm{mg}$ of EGCG depending on the mixture [88]. Although catechins are typically consumed at nontoxic doses, adverse effects like abdominal discomfort, nausea, headache, and lightheadedness have been reported following daily doses exceeded $800 \mathrm{mg}$ of EGCG for at least one month [89].

Studies showed that EGCG reduced inflammation and inhibits cell proliferation in various cancers [90,91]. EGCG effectively down-regulates cyclin dependent kinases (CDKs) such as CDK2 and CDK4 [92], induces apoptosis [93,94], and blocks angiogenesis and MMPs [95,96]—all processes that could prove beneficial outcome in preventing UF proliferation. Studies on UF animal model showed that EGCG effectively inhibited UF cells proliferation while induced cells apoptosis. EGCG significantly decreased the number and volumes of UF lesions in quails as compared to controls [97]. Several studies on rat ELT3 UF cells showed that high dose EGCG inhibited UF cell growth [86]. Treatment with EGCG led to $40 \%$ decrease in cell proliferation at 72 hours along with significant reduction of proliferation markers expression such as proliferating cell nuclear antigen (PCNA) and CDK4 proteins [86]. The same group found also that EGCG inhibits UF cell growth in a time- and dose-dependent manner. EGCG significantly inhibited cell growth after five days of exposure while a higher dose reached significance within 3 days after treatment [98]. In the same study, EGCG induced apoptosis with concentration-dependent downregulation of anti-apoptotic protein $\mathrm{Bcl} 2$ and upregulation of pro-apoptotic Bax [98]. Some genes of tumor suppressor gene p53 pathway were also upregulated in UF cells when treated with EGCG. Notably, EGCG induced apoptosis and decreased cell proliferation only in cancer but not normal cells, highlighting a favorable selective and safe effect [99]. Zhang et al observed a 14-fold increase of bone morphogenetic protein 2 (BMP2) expression in UF culture treated with EGCG compared to untreated control. BMP2 is a part of TGF- $\beta$ family and plays a vast role in cell growth, division, differentiation, and programmed cell death [98]. Thus BMP2 can act as a pro-apoptotic gene. It has been previously investigated in epithelium of the human colon [100] where inactivation of BMP2 was shown to be associated with aggressive course of prostatic cancer [101]. Therefore, the ability of EGCG to increase BMP2 activity in tumors may lead to further investigating EGCG as an option for UF treatment.

COMT enzyme, which is involved in estrogen metabolism, is overexpressed in UFs versus normal myometrium $[102,103]$. Moreover, higher amounts of COMT are observed in black women compared to white [104]. EGCG has been shown to inhibit COMT, but there is a lack of data on human model [105].

In 2013, Roshdy et al. performed a clinical trial investigating the safety and efficacy of EGCG as anti-UF treatment. Thirty-three women with symptomatic UFs received $800 \mathrm{mg}$ of EGCG daily for 4 months. The authors noted a significant decrease in UF volume, improvement in UF symptoms such as anemia, and increased health-related QoL scores as compared to controls, who reported symptom deterioration over the same period of time [106]. Recent study by Porcaro et al. [81], as we described in the vitamin D paragraph, showed a combined effect of vitamin D and EGCG with promising results.

EGCG analogs are also under extensive research. According to study by Ahmed et al. [107] the Pro-EGCG analogs 2a and 4a reduced susceptibility to COMT-mediated methylation and were found to inhibit proteasome and Akt signaling pathways. Authors concluded that these mechanisms might result in enhanced anti-proliferative, anti-angiogenic, and anti-fibrotic properties in UFs. EGCG appears to be a well-tolerated, readily available natural compound that presents promising results for treatment of UFs. Continued human clinical trials with larger cohorts and randomized control study design are essential to determine clinical effect of EGCG, alone or in combination, and measure its side effects. 


\subsubsection{Berberine}

Berberine is a plant-based alkaloid used for centuries in Chinese medicine [108]. It can be found in Scutellaria barbata, a perennial herb which exhibited anti-inflammatory and anti-tumorigenic effects [109], as well as anti-proliferative, pro-apoptotic, and anti-metastatic actions [110,111]. Lee et al. showed that berberine-rich plants reduced the proliferative effect of human chorionic gonadotropin (HCG) in UF and myometrial cells wherein the expression of PCNA and cyclin E was significantly reduced under the influence of berberine [109]. The same authors also stated that Scutalleria barbata was potent in inhibiting intracellular aromatase in myometrial and UF cells [112]. Additionally, another study showed that berberine blocked estrogen- and progesterone-induced proliferation of UF cells as well as induced UF cell apoptosis, while not affecting human normal uterine smooth muscle cells [113].

Cyclooxygenase-2 (COX2) and pituitary tumor transforming gene 1 protein (PTTG1) were found to be more expressed in UF versus myometrium [114-116]. COX2 inhibition by celecoxib decreased the growth of UF cells, while hyper-stimulation of PTTG1 promoted cell growth significantly [114-116], suggesting the important role of both in UF pathogenesis. In 2017, Chuang et al reported that both COX2 and PTTG1 were significantly inhibited by berberine in UFs cells only. Briefly, authors performed an in vivo study using nude mice inoculated subcutaneously with rat ELT3 UF cells. Mice were then treated with 5 and $10 \mathrm{mg} / \mathrm{kg}$ doses of berberine, resulting in a weight reduction of the UF tumors by $60 \%$ and $85 \%$ respectively. Berberine significantly reduced the mRNA levels and proteins of COX2, PTTG1, Ki-67, PCNA, Cyclin D1, and CDK1 in dose-dependent manner [93]. No adverse events were observed in these mice, suggesting that berberine may be a safe and effective agent in UFs management. More investigations regarding berberine mechanism of action and safety profile are needed for expansion to human clinical trials.

\subsubsection{Curcumin}

Curcumin is a yellow substance produced by some plants. It is used as food seasoning, cosmetic ingredient, or herbal supplement. Curcumin is the main natural polyphenol found in the rhizome of Curcuma longa. It has been traditionally used for decades in Asian countries as a medical herb due to its anti-microbial, anti-inflammatory, anti-tumorigenic, and anti-mutagenic properties [117]. According to the available data, curcumin might be applicable in UF therapy since it affected important UF-involved pathways [11]. It has been used in Chinese medicine formulations as a component of tumor-shrinking decoction with good effect [118]. Reports from Korea found that extracts from Curcuma zedoaria inhibited UF cell proliferation compared to normal myometrial cell as well as TGF- $\beta$ receptor 2 in UF tissue [119]. Recently, curcumin was shown to inhibit TGF- $\beta$-related endothelial-to-mesenchymal transition and attenuated endothelial cell fibrosis [120].

In addition, Malik et al. showed that curcumin had an inhibitory effect on UF cell proliferation and ECM accumulation. It induced apoptosis [121] via regulation of caspase-3 and caspase-9, extracellular signal-regulated kinases (ERKs), and nuclear factor kappa-light-chain-enhancer of activated B cells (NF-KB) [121]. Similarly, Tsuiji et al. found that curcumin can decrease UF cell proliferation through the activation of peroxisome proliferator-activated receptor $\gamma(\operatorname{PPAR} \gamma)$ and slowing down the processes in ECM [122]. Recently, Yu et al, using microarrays, found that Curcumae rhizoma in combination with Sparganii rhizoma inhibited the expression of UF cell proliferation and deposition of ECM-derived genes. Authors found that these agents were influencing the important UF-derived pathways including MAPK, PPAR, and TGF- $\beta /$ Smad signaling [123]. Lately, it was found that curcumin presents powerful anti-inflammatory and anti-oxidant activities. It stabilizes the levels of interleukin 6 (IL-6), tumor necrosis factor $\alpha$ (TNF- $\alpha$ ), ECM proteins (fibronectin and collagen), as well as a vascular endothelial growth factor (VEGF) [124].

In our opinion, data are not conclusive to recommend wide use of curcumin in UF therapy. However, it might be promising as a preventive treatment for women at high risk of developing UFs [121]. Notably, main challenges of curcumin are its low bioavailability and solubility. Yet new research about liposomal formulas showed promising results in this regard [125]. 


\subsubsection{Resveratrol}

Resveratrol is a stilbenoid polyphenol that can be found in different plant species and also in red wines. Many studies demonstrated that resveratrol possesses a high antioxidant activity and anti-tumor activity [126]. Resveratrol can also be used in preventing lipid oxidation in pharmaceutical products, delaying toxic products formation [127]. Li et al. showed that resveratrol demonstrated apoptotic and anti-proliferative effects on human cervical cancer cells through the activation of caspase-3 and -9 and upregulation of Bax expression while downregulating Bcl-2 proteins [128]. Moreover, Resveratrol showed potent anti-inflammatory activity as lowered NF- $\mathrm{KB}, \mathrm{TNF}-\alpha$, and IL-6 serum levels, as well as COX-2 activity and reactive oxygen species production in an animal model of acute pharyngitis [129].

Scutellaria barbata, which is source of berberine, also contains resveratrol, baicalin, apigenin, and luteolin. According to the study by Kim et al. on UF cells, extracted baicalin, berberine, and resveratrol did not inhibit UF growth, whereas apigenin and luteolin were effective. Authors concluded that compounds provided in Scutellaria barbata might stop the growth mediated by IGF-I in the human uterus, and may reduce tumor volume. However, the data about resveratrol was not evidenced [130]. Lately, studies have shown that resveratrol reduced the expression of ECM-related proteins like fibronectin, collagen types 1 and 3, as well as fibromodulin and biglycan. In the same study, resveratrol also reduced MMP-9 expression and increased tissue inhibitor of metalloproteinase 2 (TIMP2) protein expression in UF cells [131]. Moreover, Ho et al. stated that resveratrol inhibited UF cell proliferation through integrin $\alpha \mathrm{v} \beta 3$ pathway [132]. In the same study, resveratrol increased the expressions of pro-apoptotic genes p21 and inhibited the expression of anti-apoptotic genes. Authors also claimed it inhibited the Akt phosphorylation in UF cells [132]. Recently, data was confirmed by Chen et al. where resveratrol significantly suppressed UF growth in vivo via decreased expression of PCNA and $\alpha$-smooth muscle actin ( $\alpha$-SMA). In addition, it decreased the mRNA levels of fibronectin, collagen type 1 , and $\beta$-catenin. [133].

Collectively, these findings present a potential role of resveratrol in UF management. However, safety data is necessary to draw final conclusions. Also challenges regarding pharmaceutical compounding due to low solubility and bioavailability have been reported [126].

\subsubsection{Fucoidans}

Fucoidans are a group of highly sulphated polysaccharides found in various species of brown seaweeds and brown algae. Fucoidans have been investigated for anti-oxidant, anti-inflammatory, anti-angiogenic, and anti-cancer activity [134]. The activity of fucoidans is related to their structure and depends on carbohydrate type, sulphate content, and molecular weight. Low molecular weight fucoidans were shown to have better cell cytotoxicity in comparison to native fucoidan in cancer cell lines, whereas gamma irradiated fucoidans presented with better cell transformation inhibition [134,135]. The role of fucoidans in fibrosis was highlighted by Li et al using mouse kidney model, where they were found to inhibit TGF- $\beta 1$ induced epithelial-mesenchymal transition (EMT) and decrease expression of fibronectin and connective tissue growth factor (CTGF) [136]. A recent study by Wang et al. stated that fucoidans inhibited TGF- $\beta 1$-related epithelial-mesenchymal transition through ERK pathway in lung [137]. Wu et al. [138] obtained the same data in radiation-induced fibrosis.

Regarding effects on UFs, Chen et al. [139] showed that fucoidan caused cell growth reduction, decreased fibronectin, vimentin, $\alpha$-SMA, and the collagen protein levels. In this model, this natural compound reduced Smad2 and ERK1/2 pathways as well as $\beta$-catenin translocation. These data might suggest promising effects of fucoidans as anti-UF compound, however more basic research is necessary.

\subsubsection{Indole-3-Carbinol}

Indole-3-carbinol (I3C) is a common phytochemical compound found in cruciferous vegetables such as broccoli, Brussels sprouts, cabbage, cauliflower, and kale. Its biological activity on cellular and molecular pathways where tested mostly in cancers; however, I3C was also described as a blocking 
agent which upregulates drug-metabolizing enzymes [140]. According to current data, I3C has an influence on multiple signaling pathways and target molecules that regulate cell division, apoptosis, or angiogenesis in different known tumors, including UFs, such as PI3K/Akt/mTOR [140], as well as NF-KB [141], and promotes caspase 8-triggered apoptosis [142].

In 2020, Greco et al. showed that I3C and quercetin can regulate ECM expression, migration, and proliferation of primary UF cell. Authors found that I3C significantly decreased collagen 1 and fibronectin mRNA expression [143].

There are different clinical trials regarding the use of I3C in different cancer types and more work is still needed in research and clinical testing to start the usage of I3C for human malignancies [141]. More research is needed to support I3C as potential anti-UF agent.

\subsubsection{Isoliquiritigenin}

Isoliquiritigenin is a phenolic compound found in plants that belong to licorice including Glycyrrhiza uralensis, Mongolian glycyrrhiza, Glycyrrhiza glabra, and others. This agent can also be found in different common foods and in alternative medicine. Isoliquiritigenin is a N-methyl-D-aspartate receptor (NMDA) receptor antagonist and a gamma aminobutyric acid (GABA) modulator and a metabolite [144]. Literature showed it might play an important role in immune response, Park et al. found that it inhibited NF-KB and interferon regulatory factor 3 activation [145]. Similarly, Feldman et al found that isoliquiritigenin has a potent influence on the inflammatory response of macrophages and inhibits the activation of NF-KB [146] and suppressed TNF- $\alpha$-induced activation of adipocytes while activating peroxisome proliferator-activated receptor- $\gamma$ [147]. Additionally, isoliquiritigenin was found to have an anti-tumor effect in melanoma [148] and anti-fibrotic effect in mesangial cells via inhibition of collagen, CTGF, and TGF- $\beta 1$-smad signaling transduction [149].

Likewise in UFs, Kim et al found that UF cell proliferation was significantly reduced following isoliquiritigenin treatment in a dose-dependent manner with caspase-3 activation and Bcl-2 downregulation [150]. Other study by Lin et al found that isoliquiritigenin affected UF cell proliferation, apoptosis, and autophagy induction. Moreover, it arrested cell cycle and nucleus condensation only in UF but not myometrial cells. Isoliquiritigenin inhibited estrogen induced ERK1/2 activation as well as the expression ECM proteins and MMPs. Finally, it reduced serum levels of estradiol and progesterone levels in a mouse model [151]. These results advocate potential effect of isoliquiritigenin in treatment of UFs. However, clinical applications of this compound would be feasible after further studies.

\subsubsection{Quercetin}

Quercetin is a plant flavonol with a bitter flavor that can be found in different fruits, vegetables, leaves, and grains. This compound is often used in beverages and foods. Usual daily consumption of quercetin equals of 25-50 milligrams [152]. Isolated quercetin also can be used by some people as a dietary supplement in daily doses of up to $1000 \mathrm{mg}$, however, this might be risky in some groups [153].

Quercetin polyphenolic substructure halts oxidation and act as a scavenger of free radicals [154]. Interestingly, quercetin has been reported to have estrogenic activities, it activates both types of estrogen receptor $(\alpha$ and $\beta$ ) and available data underline that it is rather $\beta$ selective and weaker than estradiol [155]. Current studies highlighted anti-fibrotic effect of quercetin derivatives in hepatic stellate cells and showed a dose and time-dependent anti-proliferative effect. They reduced $\alpha$-SMA and collagen I mRNA as well as reduced TIMP1 mRNA expression in TGF $\beta$-induced cells [156]. In another recent study, quercetin presents with anti-fibrotic activity via influence on TGF- $\beta / A k t / m T O R$ signaling pathway. In addition, it reduced IL-6, VEGF, and expression of different collagen types [157]. For UFs, in 2020 Cavalcante et al. found that quercetin showed uterine anti-aging features via PI3K/Akt/mTOR signaling pathway. The use of quercetin together with dasatinib was found to increase p53 gene expression and decrease $m i R-34 a$ [158]. Moreover, quercetin and I3C significantly decreased collagen and fibronectin mRNA expression and the migration pattern in UFs [143]. 
Still, there is not much data about quercetin anti-UFs benefits, especially its estrogenic activity to affect tumor growth [159] as well as other sex steroid-dependent malignancies. More safety studies are needed since quercetin has been linked to nephrotoxicity [153].

\subsubsection{Sulforaphane}

Sulforaphane is a natural agent that can be found in many cruciferous vegetables like broccoli, cabbage, cauliflower, and kale. It belongs to the isothiocyanate group of organosulfur compounds. Normally isothiocyanates are not present in the cells but are produced following cell wall destruction (e.g., by chewing). Sulforaphane is believed to play a role as a cytoprotective and chemopreventive agent [160], especially in carcinogenesis and fibrosis via alterations of the ECM [161]. For example, it was shown to protect the liver from fibrosis in an animal model [162]. A study explained fibrosis inhibition through modulation of the nuclear factor erythroid 2-related factor 2 (Nrf2) signaling that is involved in TGF- $\beta$ signaling pathway [163]. It also attenuated pulmonary fibrosis by inhibiting the epithelial-mesenchymal transition, it decreased expression of N-cadherin, vimentin, and $\alpha$-SMA [164]. Similarly, Fix et al found that sulforaphane inhibited TGF- $\beta 1$ induced myofibroblast formation and reduces expression of integrins via inhibiting canonical and non-canonical TGF- $\beta$ signaling pathways [161]. Another study confirmed the same findings in addition to decreased expression of various cytokines, TNF- $\alpha$, and IL-6 [165].

There is not much data about the use of sulforaphane in UFs. However, recently Islam et al. presented their preliminary results where they found that sulforaphane inhibited UF cell proliferation and gene expression associated with inflammation and UF growth. Authors suggested that the use of this compound might find a place in the area of UFs [166]. However, more research is still required.

\subsubsection{Anthocyanins}

Anthocyanins are water-soluble flavonoid pigments that may be present with red, purple, blue, or black color. Plants that are rich in those pigments include blueberries, raspberries or strawberries [167]. According to two studies, strawberries anthocyanin are of special interest in UFs [168-170]. Strawberries have anti-inflammatory, anti-oxidative, anti-proliferative, and genomic protective effects $[169,171]$. Islam et al. studied the effect of a variety of strawberry Alba cultivar extract on apoptosis, fibrosis, oxidation, and other processes in myometrium and UF cells. Authors found that anthocyanin-rich strawberries induced apoptosis and suppressed glycolysis and fibrosis in UFs cells as compared to control. Following strawberry treatment, authors observed an increase in reactive oxygen species levels in UFs. Additionally, anthocyanin-rich extract significantly reduced fibronectin, collagens, and versican mRNA expression in UF cells compared to untreated cells [168]. A recent study tested five different strawberry cultivars to identify which one presents the best phytochemical profile as an anti-UF agent. Authors found that $A l b a$ (same as in study above) and Romina cultivars presented the best results, with decreased collagen 1A1, fibronectin, versican, and activin A mRNA expression in UF cells [169]. Strawberry and its potent anthocyanins might offer therapeutic or preventive spectrum in UF treatment. However, further animal studies and then clinical trials are needed. These studies also emphasize that healthy diet rich in fruits like strawberries might be helpful for women with UFs.

\subsubsection{Omega-3 Fatty Acids}

Omega-3 fatty acids are polyunsaturated fatty acids (PUFAs). They are widely distributed in nature, being important in diet and having great impact on lipid metabolism. There are three major omega-3 fatty acids: Alpha-linolenic acid (ALA), eicosapentaenoic acid (EPA), and docosahexaenoic acid (DHA). ALA is found mainly in plant oils whereas DHA and EPA are common in fish and other seafood [172]. Humans, like other mammals, are not able to synthesize ALA and can only obtain it through diet. However, ALA can be transformed in humans to EPA and DHA by simple modifications.

Omega-3 fatty acids play an important role in cellular function [173]. Despite many hypothesis and optimistic preliminary studies, dietary supplementation with omega-3 fatty acids did not affect 
the total risk of cardiovascular disease, cancer, or death [174]. Omega-3 fatty acids present with anti-inflammatory and immunomodulatory effects and might be potential therapeutic agents for inflammatory and autoimmune diseases [175] through decreasing the levels of C-reactive protein, IL-6, and TNF- $\alpha$ [176]. Since some of these pro-inflammatory molecules were found to be involved in the pathophysiology of UFs, omega-3 fatty acids were studied in that context. Islam et al. stated that myometrium has higher amount of arachidonic acid than UFs with ALA being higher in UFs. Treatment with EPA and DHA reduced the monounsaturated fatty acids content in UFs and controls. However, these did not reflect changes in the mRNA expression of ECM components. Omega-3 fatty acids reduced the levels of sterol regulatory molecules (e.g., ATP-binding cassette sub-family G member 1-ABCG1 or ATP-binding cassette transporter member 1-ABCA1) in both cell types. It also reduced cytochrome 450 family member-CYP11A1, the mitochondrial enzyme that catalyzes the conversion of cholesterol to pregnenolone. Authors concluded that omega-3 fatty acids modulate lipid profile, mechanical signaling, and cellular lipid accumulation in UFs [177]. Pregnenolone is a precursor for biosynthesis of many steroid hormones including progestogens, which is an important hormone in UF biology. This is an interesting line of thinking warranting further investigation.

\subsubsection{Methyl Jasmonate}

Methyl jasmonate is a natural derivative of jasmonic acid, which plays a role in plant defense, germination, growth, ripening, and senescence. Methyl jasmonate can induce the plant to produce anti-microbial phytoalexins, nicotine, or protease inhibitors $[178,179]$ through interaction with NF- $\mathrm{kB}$ signaling pathways which is involved in various inflammatory cascades and regulate adaptive immune responses [180]. Accordingly, methyl jasmonate was tested and found to have a potent impact on cancer cells where it induced cytochrome $\mathrm{C}$ release in the mitochondria leading to cell death [181]. Methyl jasmonate showed antioxidant functions in adjuvant-induced arthritic rat models [182]. Umukoro et al. explained a membrane-stabilizing effect of methyl jasmonate [183]. Pereira-Marostica et al. in 2019 worked on brains of Holtzman rats with adjuvant-induced arthritis and found that it prevented arthritis-induced increased levels of nitrates, lipid peroxides, and reactive oxygen species [184]. A recent study by Ribera-Fonseca et al. highlighted the significant inhibition of gastric cancer cell migration and expression of different proteins related to the MAPK pathway in response to methyl jasmonate [185].

Methyl jasmonate inhibited enhancer of zeste homolog 2 (EZH2) activity which is linked with different tumors, including both benign, like UFs, and malignant types [186,187]. Ali et al. showed that methyl jasmonate demonstrated potent selective anti-proliferative effect on UF cells, even in low concentrations, as compared to myometrial cells. Moreover, methyl jasmonate decreased RNA levels of EZH2, collagen 1A1, fibronectin, cyclin D1, PCNA, and $\beta$-catenin, while increasing expression of p21, Bax, and cleaved caspase 3 in UF cells in comparison to untreated control [186]. This novel compound might be a potential anti-UF candidate warranting further investigation.

\subsubsection{Lycopene}

Available data suggest a reduced risk of UFs among women with a greater dietary intake of fruit and vitamin A [188]. Lycopene is a phytonutrient of carotenoid family, defining the orange and red color of many widely consumed fruit and vegetables including tomatoes, carrots, papaya, and watermelon. Free radicals cause oxidative damage to tissues leading to disturbances in cell proliferation and differentiation. This results in DNA alterations potentially leading to cancer development $[189,190]$. Carotenoids are well-known antioxidants that protect cells from the above-mentioned processes [191-194]. Rao and Agarwal found that serum lycopene levels are low in patients with chronic illnesses and oxidative stress. In the same study, they have observed a significant decrease in thiobarbiturate-reactive substance, a marker of oxidative stress, in individuals supplemented with lycopene [195]. Many studies have shown that lycopene intake decreased the incidence of lung, prostatic, breast, cervical, and gastrointestinal cancers in humans [196-199]. 
Unfortunately, data linking UFs and carotenoids are not that consistent. In 2008, an interesting study by Terry et al was performed on more than 82,000 patients and total lycopene intake was not associated with UF risk. On the other hand, the intake of beta-carotene was associated with slightly increased risks of UF diagnosis, but this was restricted only to women who smoke. Thus, authors concluded that their findings did not suggest that carotenoids reduce the risk of diagnosed UFs, and there is only small risk in current smokers [200]. Since lycopene works in part to modulate the synthesis of cell cycle regulating proteins [201] and thus induces an anti-proliferative effect and regulates anti-tumor immunity [202]. Sahin et al. studied the effect of lycopene supplementation on oviduct fibroids in Japanese quails and observed a lower incidence of tumors and dose-dependent reduction of tumor size in the treatment versus control group. The treated Japanese quails also had significantly lower levels of oxidative stress biomarkers, including homocysteine and malondialdehyde, and higher serum amounts of antioxidant vitamins A, C, and E compared to untreated controls [203]. In another in vivo study, Sahin et al. tested the effects of diet derived lycopene by treating Japanese quails with different doses of tomato powder. After one year of supplementation, the treated quails had a significantly decreased number of UFs as compared to control [204]. Tomatoes contain not only lycopene, but also other active nutrient substances, like folate, phenolics, vitamins $A$ and $C$, and flavonoids [205], which are also known to possess antioxidant activity [206]. An inverse correlation between tomato intake and risks for various tumors, including prostatic, lung, pancreatic, gastric, cervical, and ovarian cancers has been shown [207]. Additional carotenoids in tomatoes, like phytoene and phytofluene, may have an additive effect with lycopene, thus potentiating the antioxidant action.

Lycopene has a promising potential role in UF management. Lycopene is well tolerated and widely consumed in many global diets. It deserves more research attention to achieve proper dosing, efficacy, and tolerability.

\subsubsection{Collagenase Clostridium histolyticum}

Collagenase is an enzyme that has an effect on collagen and produced by the bacterium Clostridium histolyticum [208]. Since the year 2010, after approval from United States FDA, it has been widely used for fibrotic-dependent disease, e.g., in Dupuytren's contracture [209]. Since UFs contain a great percentage of abundant and disorganized collagen-rich ECM, this anti-collagen enzyme may serve as an efficient non-hormonal treatment option. Brunengraber et al. assessed the potential utility of this agent as treatment for UFs in human samples collected after hysterectomy. Authors found that the relative percentage of collagen-stained area in UF-injected samples was less than that in both control samples and treated myometrium. The main limitation is the heterogeneity of ECM and collagen which might contribute to varied responses and needs additional studies [209]. Jayes et al. used a highly purified collagenase Clostridium histolyticum to explore how it reduces the stiffness of UF tumor. The authors used 3 doses of collagenase. Longer incubation time caused greater reduction in tumor stiffness, shape, and consistency. The authors concluded that the reduction of tissue stiffness is of much importance as it might decrease bulk symptoms and lead to UF volume decrease, probably leading also to pain and bleeding reduction [210]. These promising data brought this agent to the first phases of clinical trials where it was studied in humans.

In a study by Singh et al. [211], 15 women with UFs who had planned surgical treatment were enrolled in a trial to test how collagenase Clostridium histolyticum acts in living humans. Authors injected the collagenase into lesions which were later removed during hysterectomy. This was the first study to check the potential safety and tolerability of collagenase injection and change in collagen content was checked. Authors found that treated samples had an average of $21 \%$ reduction in density of collagen bundles in comparison to controls. Moreover, the digestion of collagen did not extend the capsule of any lesion. Thus, no adverse drug reactions or adverse event were reported by patients. As for symptoms, patients reported a decrease of pain after drug injection [211].

In our opinion, this promising compound is unique in UFs management. Most of the discussed agents are used orally or intravenously while this one is the first to be injected directly to the lesion 
during different procedures, like in out-patient clinics with the use of ultrasound and long needle, or during surgeries like hysteroscopy and laparoscopy. Of course, this has some advantages and disadvantages as well. The advantage is that this will be a rather selective treatment of individual lesions. The disadvantage is this will be a new, safe form of non-invasive treatment. A new intrauterine system releasing such collagenase would be interesting, but requires further research.

We summarize the available compounds in Figure 3.
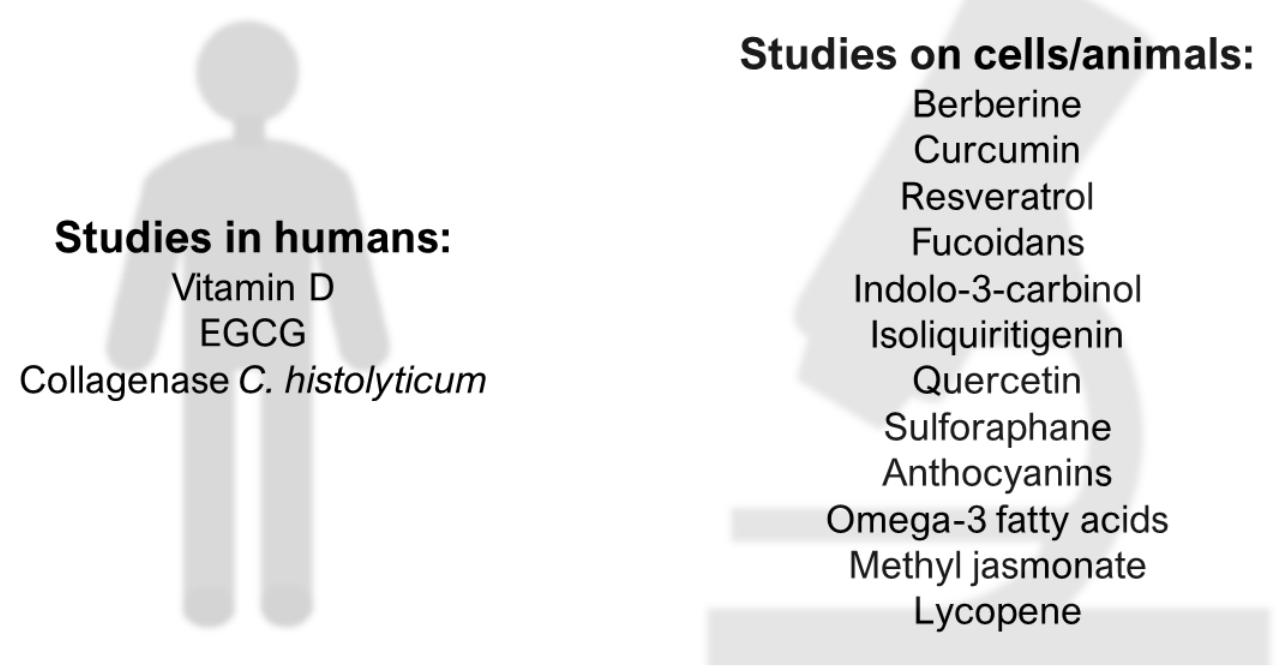

Figure 3. Promising natural anti-UF compounds. Epigallocatechin gallate-EGCG.

The most important pathways and effects of described natural compounds are presented in Table 1.

\subsection{Bioavailability of Natural Compounds}

Bioavailability is crucial step to ensure the bio-efficacy of natural compounds. It is a complex process including liberation, absorption, distribution, metabolism, and elimination phases (LADME). Natural compounds need to be bioavailable in order to exert their beneficial effects. Many variables can affect their bioavailability, such as bio-accessibility, transporters, molecular structures, and metabolizing enzymes. Since hydrophilic and lipophilic bioactive compounds have different mechanisms of absorption, the bioavailability of these compounds is challenging. Several technologies have been developed to enhance the bioavailability including structural modifications, nanotechnology, and colloidal systems. Surprisingly, there is little data on factors that affect absorption of natural compounds [212]. 
Table 1. Most important pathways and effects of natural anti-UF compounds.

\begin{tabular}{|c|c|}
\hline Compound & Molecular Target \\
\hline Vitamin D & $\begin{array}{c}\text { MMPs inhibition } \\
\text { Catechol-O-methyltransferase suppression } \\
\text { TGF- } \beta \text { induced ECM production inhibition } \\
\text { Wnt/ } \beta \text {-catenin pathway inhibition } \\
\text { Steroid receptor expression decrease } \\
\text { Anti-inflammatory effect } \\
\text { Apoptosis induction/proliferation inhibition }\end{array}$ \\
\hline EGCG & $\begin{array}{c}\text { MMPs inhibition } \\
\text { Catechol-O-methyltransferase suppression } \\
\text { Anti-inflammatory effect } \\
\text { Apoptosis induction/proliferation inhibition } \\
\text { BMP2 expression upregulation }\end{array}$ \\
\hline Berberine & $\begin{array}{l}\text { Cyclooxygenase } 2 \text { inhibition } \\
\text { Anti-inflammatory effect } \\
\text { PTTG1 inhibition } \\
\text { Apoptosis induction }\end{array}$ \\
\hline Curcumin & $\begin{array}{c}\text { PPAR } \gamma \text { activation } \\
\text { TGF- } \beta \text { induced ECM production inhibition } \\
\text { Apoptosis induction } \\
\text { Anti-inflammatory effect }\end{array}$ \\
\hline Resveratrol & $\begin{array}{l}\text { MMPs inhibition } \\
\text { ECM production inhibition } \\
\text { Apoptosis induction }\end{array}$ \\
\hline Fucoidan & $\begin{array}{l}\text { Epithelial-mesenchymal transition } \\
\text { inhibition } \\
\text { ECM production inhibition } \\
\text { Wnt } / \beta \text {-catenin pathway inhibition }\end{array}$ \\
\hline Indolo-3-carbinol & $\begin{array}{l}\text { ECM production inhibition } \\
\text { Anti-inflammatory effect } \\
\text { Apoptosis induction }\end{array}$ \\
\hline Isoliquiritigenin & $\begin{array}{l}\text { MMPs inhibition } \\
\text { ECM production inhibition } \\
\text { Anti-inflammatory effect } \\
\text { Apoptosis induction }\end{array}$ \\
\hline
\end{tabular}

Effect on steroid receptors

\begin{tabular}{|c|c|}
\hline Quercetin & $\begin{array}{c}\text { TGF- } \beta \text { induced ECM production inhibition } \\
\text { Anti-inflammatory effect }\end{array}$ \\
\hline Sulforaphane & $\begin{array}{l}\text { Effect on TGF- } \beta \text { pathway } \\
\text { Anti-inflammatory effect }\end{array}$ \\
\hline Anthocyanins & $\begin{array}{l}\text { ECM production inhibition } \\
\text { Anti-inflammatory effect }\end{array}$ \\
\hline $\begin{array}{l}\text { Omega-3 fatty } \\
\text { acids }\end{array}$ & $\begin{array}{l}\text { Anti-inflammatory effect } \\
\text { Lipid profile modulation }\end{array}$ \\
\hline $\begin{array}{c}\text { Methyl } \\
\text { jasmonate }\end{array}$ & $\begin{array}{c}\text { Enhancer of zeste homolog } 2 \text { inhibition } \\
\text { ECM production inhibition } \\
\text { Wnt } / \beta \text {-catenin pathway inhibition } \\
\text { Apoptosis induction }\end{array}$ \\
\hline Lycopene & $\begin{array}{l}\text { Immunomodulation } \\
\text { Apoptosis induction }\end{array}$ \\
\hline $\begin{array}{l}\text { Collagenase } C . \\
\text { histolyticum }\end{array}$ & ECM degradation \\
\hline
\end{tabular}

Bone morphogenetic protein 2-BMP2; extracellular matrix-ECM; metalloproteinases-MMPs; peroxisome proliferator-activated receptor $\gamma$-PPAR $\gamma$; pituitary tumor transforming gene 1 protein-PTTG1; transforming growth factor beta-TGF- $\beta$; wingless-type signaling pathway-Wnt. 
Fat-soluble vitamin D, ergocalciferol, the form mostly used in supplements and fortified foods, is apparently absorbed with similar efficiency to cholecalciferol (vitamin D3, the main dietary form). Moreover, $25(\mathrm{OH}) \mathrm{D}$, the metabolite produced in the liver, and which can be found in foods, is better absorbed than the non-hydroxy vitamin D forms cholecalciferol and ergocalciferol. Studies also concluded there is insufficient, or even no data, on the effect of type and amount of dietary fiber, vitamin D status, and genetic variation in proteins involved in its intestinal absorption on vitamin $\mathrm{D}$ bioavailability [213]. Despite all of its pleiotropic properties, most of EGCG's health-promoting effects are compromised following oral administration due to its poor intestinal permeability and stability [214]; however, its promising effects have attracted increasing interest to scientists in the last decades to improve its bioavailability. For example, folic acid-functionalized nanostructured lipid carriers (NLC) loading EGCG has been recently developed to increase its oral bioavailability [215]. Certain studies highlighted low curcumin bioavailability, but it has been addressed by using higher concentrations of curcumin within nontoxic limits. Moreover, curcumin, in combination with other compounds or as formulations, has shown enhanced bioavailability. Hence, bioavailability is not a problem in the curcumin-mediated treatment of chronic diseases [216]. Additionally, several formulations have been developed and showed better bioavailability mostly attributed to improved solubility, stability, and possibly low first-pass metabolism [217]. Resveratrol is extensively metabolized and rapidly eliminated and therefore it shows a poor bioavailability, in spite it of its lipophilic nature. During the past decade, in order to improve its low aqueous solubility, absorption, membrane transport, and its poor bioavailability, various methodological approaches and different synthetic derivatives have been developed like nanoencapsulation in lipid nanocarriers or liposomes [218]. Studies are still running for better understanding of cruciferous vegetables and sulforaphane bioavailability [219]. The absolute bioavailability of quercetin in humans was estimated at $44.8 \%$ and half-life in the range of $11-28 \mathrm{~h}$; this indicates a likely significant increased plasma concentration consequent to continuous supplementation [220]. Lycopene has a low bioavailability rate and appears in the blood circulation incorporated into chylomicrons and other apo-B containing lipoproteins. The recent body of evidence suggests that plasma concentration of lycopene is not only a function of intestinal absorption rate but also lycopene breakdown via enzymatic and oxidative pathways in blood and tissues. Its bioavailability depends on various factors such as food processing or co-ingestion of fat $[221,222]$.

\subsection{Clinical Application of Natural Compounds in UFs Management}

The concept of using complementary and alternative medicine (CAMs) in therapy was established centuries ago. Plants and herbs are key parts of traditional medicine. Additionally, pharmacology was initially based on natural compound before it shifted heavily towards synthetic agents. Still, numerous drugs in use are of natural origin and are heavily studied nowadays, especially in oncology. In their review, Newman and Cragg encouraged further exploration of natural compounds instead of only focusing on synthetic agents. Natural compounds may still serve as efficacious drugs for a multitude of disease indications [223]. Nonetheless, several challenges including poor bioavailability of some dietary phytochemicals, instability associated with $\mathrm{pH}$ and/or enzyme-mediated degradation, nonselective effects, and finally the need of non-physiological concentration to cause the clinical effect might explain why some of these promising compounds did not progress beyond laboratories to find their place in clinical practice. However, advances in formulation or agent modification might help [224].

According to the 2012 National Health Interview Survey (NHIS), which included a comprehensive survey on the use of complementary health approaches by Americans, $17.7 \%$ of US adults had used a dietary supplement other than vitamins and minerals in the past year [225]. The National Institutes of Health (NIH) is dedicated to highlighting the usage of CAM as a way to encourage more research in this field via the National Center for Complementary and Integrative Health (NCCIH). By the definitions provided by the $\mathrm{NCCIH}$, complementary therapies are used in conjunction with conventional medicine, whereas alternative therapies are used in place of conventional medicine. 
In this manuscript, we emphasized potential dietary phytochemicals for UF treatment to be used as complementary or alternative medicines, or both, depending on individual patient preferences and treatment plan. The anti-hormonal effect is common in current anti-UF therapies with adverse effects of hot flashes, loss of bone mineral density, vaginal dryness, and benign endometrial changes $[49,55]$. Oral GnRH analogs, like elagolix, are combined with add-back therapy to decrease these adverse effects but still some patients might experience difficulties [50]. There are also some concerns about other hormonal agents in this indication, such as UPA, which might be connected with liver toxicity [57]. Furthermore, there are no currently available medical options for UFs in women who wish to conceive or during pregnancy. The desire to avoid these side effects, stress connected with potential surgery, and further fertility plans drive the demand for non-hormonal treatments like naturally derived compounds [11,226]. Although UFs prevalence peaks in the 40s age range, Marsh et al. have shown that UF are present in 15\% of asymptomatic women aged 18-30 using ultrasound [227]. Thus, women at higher risk of developing UFs, including those with family history, black race, or delayed childbearing may benefit from naturally-derived compounds to slow or halt UF proliferation or prevent UF development $[7,61]$. Several reviewed compounds in this article show promise as natural CAM therapies for women with UFs since they affect numerus important pathways involved in UFs, e.g., inflammation, growth factors, angiogenesis, fibrosis, and cell proliferation (cycle arrest or apoptosis) [224].

The link between hypovitaminosis $\mathrm{D}$ and incidence of many diseases is clear. The American College of Obstetricians and Gynecologists (ACOG) recommends 600 international units (IU) of vitamin D daily for pregnant and lactating women [228]. Most prenatal vitamins typically contain 400 IU of vitamin D per tablet. When vitamin D deficiency is identified during pregnancy, ACOG states that 1000-2000 IU of vitamin D per day is safe. Although ACOG noted that higher dose regimens used for the treatment of vitamin D deficiency have not been studied during pregnancy, it also states that some experts support supplemental vitamin D in dosages up to $4000 \mathrm{IU}$ per day during pregnancy or lactation [228]. Target 25(OH)D serum levels should be about 30-50 ng/ml [62,229]. Research on the impact of vitamin D treatment for UF in humans should use these doses as guidelines.

Tea is one of the most commonly consumed beverages worldwide. Green tea, although most commonly consumed in East Asia, is increasingly popular in the United States due to the many reported health benefits and as a source of caffeine. It is available in brewed drinks as well as powders, oral supplements, and is an additive in food products from energy drinks to ice cream. The current recommendations on caffeine consumption in pregnancy and women seeking conception state that moderate use, less than $200 \mathrm{mg}$ of caffeine per day, appears to be safe [230]. Pregnancy outcomes thought to be associated with large caffeine use include miscarriage, preterm birth, and intrauterine growth restriction. Of these, moderate caffeine consumption does not appear to be a contributing factor based on the literature available to date [230]. Polyphenols, such as EGCG, in green tea may play a role in mammalian metabolism [231]. Concerns regarding increased polyphenol intake during pregnancy have focused on maternal metabolism during pregnancy and intrauterine growth restriction of offspring. Whether these outcomes are associated with green tea use in humans remains to be determined [231]. Animal studies have shown possible decrease in maternal diabetes-associated congenital malformations, such as neural tube defects due to EGCG exposure during pregnancy [232]. However, given the widespread consumption of green tea throughout the world, including during women's reproductive years, the recommendation for moderate consumption in the brewed form appears reasonable. Eight ounces of brewed tea averages about $50 \mathrm{mg}$ of caffeine [230]. Therefore 1-4 servings daily would keep one within the recommended range for caffeine consumption. Regarding EGCG supplementation, future studies should aim to provide dosing similar to what is found in 8-32 ounces (1-4 servings) of green tea daily to examine the safety profile of a commonly consumed and recommended dose. The idea of combining vitamin D with EGCG is also of potential interest [81].

Berberine may be less commonly used in the United States but is reportedly widely used in Eastern medicine therapies. In China, a total of 800 million $0.1 \mathrm{mg}$ tablets were consumed in 2000, 
increasing to 5.9 billion in 2013 [233]. In Western medicine, variation in product quality is an issue with pharmacologic use, which could pose a barrier to berberine's safety and effectiveness in clinical practice [234]. Further, berberine consumption in the United States is often associated with ingestion of goldenseal or yellow root, a plant native to North America. Pregnant or breastfeeding women should not use goldenseal, and it should not be given to infants due to hepatotoxicity [235]. Berberine has been studied in reproductive aged women with obesity and polycystic ovarian syndrome. Lin et al. investigated the effect of consuming $0.4 \mathrm{~g}$ berberine three times daily for four months in 102 anovulatory Chinese women with polycystic ovarian syndrome [236]. All women received the treatment and were analyzed according to normal weight versus overweight/obese. The treatment was reported to be well-tolerated in all women and only one woman reported gastrointestinal upset. Although this prospective cohort study showed participants improvements in ovulation and regulation of menses, all women were advised to use contraception during the study period given the concern of potential teratogenicity. Later studies have included berberine utility for women seeking conception as an ovulation induction agent like clomiphene citrate or letrozole [233]. More laboratory and human clinical trials are necessary to better understand the safety profile and efficacy of berberine for UF treatment.

Traditionally, studies showed that the risk of UF development was inversely associated with the intake of vegetables and fruit and increased with beef and ham consumption [237]. In 2011, Wise et al. found that UFs risk was not associated with dietary intake of vitamins $C$ and $E$, folate, fiber, and carotenoids [188].

\subsection{Future Direction}

There is an urgent need to find cost-effective, safe, and effective drugs for the prevention and treatment of UFs. Vitamin D is a natural supplement with pleiotropic action and the potential to prevent UF development and growth and deserves great attention and further investigation [63,84]. Similarly, EGCG also showed good laboratory and clinical data. Further reports are necessary to prove the efficacy of EGCG supplementation in women. The concept of combining their therapeutic effects could be additive and translates into an effective clinical therapy [224] especially given their good safety profiles. Further combinations of CAMs should be also considered against UFs. We might also search for less popular compounds, e.g., Chinese formulas, which were found to adjust the influence of mifepristone in reducing the volume of UFs and improve the symptoms of dysmenorrhea [238]. Studies about potential synergism between new oral GnRH analogs like elagolix, relugolix, and linzagolix and presented CAMs might also show interesting results. The concept of available possibilities in co-drugs is described in Figure 4, were we have included the summarized data from this manuscript with the current and emerging therapies available in UFs as presented by Chwalisz et and Taylor [239].

Additionally, considering synthetic analogs of natural compounds might be worth pursuing as well to overcome any bioavailability or dosing challenges. This can be shown for vitamin D and curcumin. Halder et al found that vitamin D analog paricalcitol exhibited more UFs size reduction compared to active vitamin D. Authors suggested that paricalcitol may be a potential candidate for effective, safe option in UFs [75]. Likewise, potent curcumin analog EF24 killed cells and inhibited TNF- $\alpha$-induced-inflammation pathways with approximately ten fold stronger effect than natural curcumin [240]; however, there is no data about utility of this compound in UFs. 


\section{Concepts for the future}
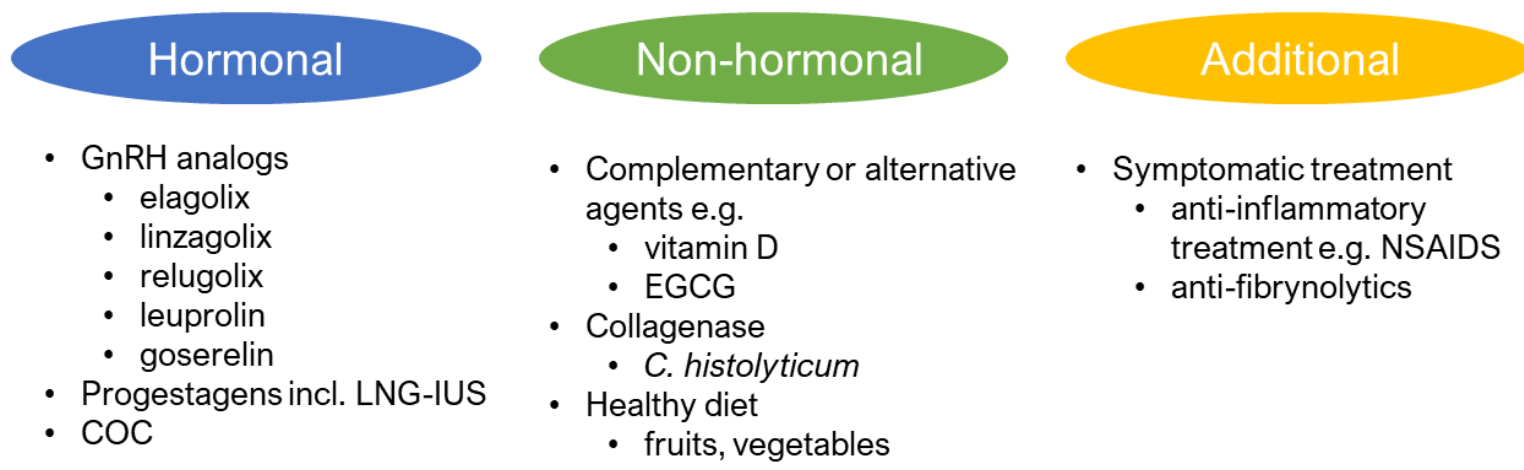

Figure 4. Current concepts on the use of natural anti-UF compounds. combined oral contraception-COC; epigallocatechin gallate-EGCG; gonadotropin-releasing hormone-GnRH; levonorgestrel-releasing intrauterine system-LNG-IUS; nonsteroidal anti-inflammatory drugs—NSAIDS.

\section{Conclusions}

UFs remain a significant health issue for many women, and they disproportionately impact women of color. As new pharmaceutic medical options emerge, natural compounds should also be considered as potential options for UF management and prevention. For example, vitamin D or EGCG should be tested in human clinical trials to establish its safety and clinical effect. Other compounds are promising in in vitro or in vivo models. However, they need further research to determine mechanism of action and safety profile in reproductive aged women. The concept of combined patient-tailored therapies is valid for further investigation and can be combined with the known agents to achieve better results.

Author Contributions: Conceptualization, M.C., M.A.; T.J.-B.; I.A., and A.A.-H.; methodology, M.C., M.A.; validation, M.C., M.A., L.P., A.A.-H.; formal analysis, M.C., M.A., A.A.-H.; data curation, M.C., M.A., T.J.-B., I.A., S.Z.; writing—original draft preparation, M.C., M.A., L.P., T.J.-A., I.A., S.Z., A.A.-H.; writing—review and editing, A.A.-H.; visualization, M.C., M.A., A.A.-H.; supervision, M.C., M.A., A.A.-H.; funding acquisition, A.A.-H. All authors have read and agreed to the published version of the manuscript.

Funding: This study was supported in part by the US National Institutes of Health grants: R01 HD094378-04, R01 ES 028615-02, R01 HD100367-01, U54 MD007602 and R01 HD094380-02.

Acknowledgments: Michał Ciebiera scholarship at University of Illinois at Chicago was founded by The Kosciuszko Foundation, The American Center of Polish Culture.

Conflicts of Interest: Ayman Al-Hendy is a consultant for Abbvie, Allergan, Bayer, Myovant Sciences and Repros. Tia Jackson-Bey has an authorship agreement with Allergan plc without any financial or commercial relationship. No conflicts were declared for the remaining authors.

\section{References}

1. Stewart, E.A.; Cookson, C.L.; Gandolfo, R.A.; Schulze-Rath, R. Epidemiology of uterine fibroids: A systematic review. BJOG 2017, 124, 1501-1512. [CrossRef] [PubMed]

2. Wise, L.A.; Laughlin-Tommaso, S.K. Epidemiology of uterine fibroids: From menarche to menopause. Clin. Obstet. Gynecol. 2016, 59, 2-24. [CrossRef] [PubMed]

3. Stewart, E.A.; Laughlin-Tommaso, S.K.; Catherino, W.H.; Lalitkumar, S.; Gupta, D.; Vollenhoven, B. Uterine fibroids. Nat. Rev. Dis. Primers 2016, 2, 16043. [CrossRef] [PubMed]

4. Murji, A.; Bedaiwy, M.; Singh, S.S.; Bougie, O.; Committee, C.R.S. Influence of ethnicity on clinical presentation and quality of life in women with uterine fibroids: Results from a prospective observational registry. J. Obstet. Gynaecol. Can. 2019. [CrossRef]

5. Herve, F.; Katty, A.; Isabelle, Q.; Celine, S. Impact of uterine fibroids on quality of life: A national cross-sectional survey. Eur. J. Obstet. Gynecol. Reprod. Biol. 2018, 229, 32-37. [CrossRef] 
6. Merrill, R.M. Hysterectomy surveillance in the United States, 1997 through 2005. Med. Sci Monit 2008, 14, CR24-CR31.

7. Al-Hendy, A.; Myers, E.R.; Stewart, E. Uterine fibroids: Burden and unmet medical need. Semin. Reprod. Med. 2017, 35, 473-480. [CrossRef]

8. Harrington, A.; Bonine, N.G.; Banks, E.; Shih, V.; Stafkey-Mailey, D.; Fuldeore, R.M.; Yue, B.; Ye, J.M.; Ta, J.T.; Gillard, P. Direct costs incurred among women undergoing surgical procedures to treat uterine fibroids. J. Manag. Care Spec. Pharm. 2020, 26, S2-S10. [CrossRef]

9. Cardozo, E.R.; Clark, A.D.; Banks, N.K.; Henne, M.B.; Stegmann, B.J.; Segars, J.H. The estimated annual cost of uterine leiomyomata in the United States. Am. J. Obstet. Gynecol. 2012, 206, e211-e219. [CrossRef]

10. Soliman, A.M.; Yang, H.; Du, E.X.; Kelkar, S.S.; Winkel, C. The direct and indirect costs of uterine fibroid tumors: A systematic review of the literature between 2000 and 2013. Am. J. Obstet. Gynecol. 2015, 213, 141-160. [CrossRef]

11. Ciebiera, M.; Lukaszuk, K.; Meczekalski, B.; Ciebiera, M.; Wojtyla, C.; Slabuszewska-Jozwiak, A.; Jakiel, G. Alternative oral agents in prophylaxis and therapy of uterine fibroids-an up-to-date review. Int J. Mol. Sci. 2017, 18. [CrossRef] [PubMed]

12. Mahase, E. Uterine fibroid drug is recalled after case of liver failure requiring transplant prompts EU review. BMJ 2020, 368, m1112. [CrossRef] [PubMed]

13. Ulin, M.; Ali, M.; Chaudhry, Z.T.; Al-Hendy, A.; Yang, Q. Uterine fibroids in menopause and perimenopause. Menopause 2020, 27, 238-242. [CrossRef] [PubMed]

14. Yang, Q.; Diamond, M.P.; Al-Hendy, A. Early life adverse environmental exposures increase the risk of uterine fibroid development: Role of epigenetic regulation. Front. Pharmacol. 2016, 7, 40. [CrossRef] [PubMed]

15. Protic, O.; Toti, P.; Islam, M.S.; Occhini, R.; Giannubilo, S.R.; Catherino, W.H.; Cinti, S.; Petraglia, F.; Ciavattini, A.; Castellucci, M.; et al. Possible involvement of inflammatory/reparative processes in the development of uterine fibroids. Cell Tissue Res. 2016, 364, 415-427. [CrossRef] [PubMed]

16. Elhusseini, H.; Elkafas, H.; Abdelaziz, M.; Halder, S.; Atabiekov, I.; Eziba, N.; Ismail, N.; El Andaloussi, A.; Al-Hendy, A. Diet-induced vitamin D deficiency triggers inflammation and DNA damage profile in murine myometrium. Int. J. Womens Health 2018, 10, 503-514. [CrossRef]

17. Makinen, N.; Mehine, M.; Tolvanen, J.; Kaasinen, E.; Li, Y.; Lehtonen, H.J.; Gentile, M.; Yan, J.; Enge, M.; Taipale, M.; et al. MED12, the mediator complex subunit 12 gene, is mutated at high frequency in uterine leiomyomas. Science 2011, 334, 252-255. [CrossRef]

18. Bulun, S.E. Uterine fibroids. N Engl. J. Med. 2013, 369, 1344-1355. [CrossRef]

19. Halder, S.K.; Laknaur, A.; Miller, J.; Layman, L.C.; Diamond, M.; Al-Hendy, A. Novel MED12 gene somatic mutations in women from the southern united states with symptomatic uterine fibroids. Mol. Genet. Genomics 2015, 290, 505-511. [CrossRef]

20. McWilliams, M.M.; Chennathukuzhi, V.M. Recent advances in uterine fibroid etiology. Semin. Reprod. Med. 2017, 35, 181-189. [CrossRef]

21. Islam, M.S.; Ciavattini, A.; Petraglia, F.; Castellucci, M.; Ciarmela, P. Extracellular matrix in uterine leiomyoma pathogenesis: A potential target for future therapeutics. Hum. Reprod. Update 2018, 24, 59-85. [CrossRef] [PubMed]

22. Ciebiera, M.; Wlodarczyk, M.; Wrzosek, M.; Meczekalski, B.; Nowicka, G.; Lukaszuk, K.; Ciebiera, M.; Slabuszewska-Jozwiak, A.; Jakiel, G. Role of transforming growth factor beta in uterine fibroid biology. Int. J. Mol. Sci. 2017, 18. [CrossRef]

23. Sozen, I.; Arici, A. Interactions of cytokines, growth factors, and the extracellular matrix in the cellular biology of uterine leiomyomata. Fertil. Steril. 2002, 78, 1-12. [CrossRef]

24. Ishikawa, H.; Ishi, K.; Serna, V.A.; Kakazu, R.; Bulun, S.E.; Kurita, T. Progesterone is essential for maintenance and growth of uterine leiomyoma. Endocrinology 2010, 151, 2433-2442. [CrossRef]

25. Borahay, M.A.; Al-Hendy, A.; Kilic, G.S.; Boehning, D. Signaling pathways in leiomyoma: Understanding pathobiology and implications for therapy. Mol. Med. 2015, 21, 242-256. [CrossRef]

26. Ciarmela, P.; Islam, M.S.; Reis, F.M.; Gray, P.C.; Bloise, E.; Petraglia, F.; Vale, W.; Castellucci, M. Growth factors and myometrium: Biological effects in uterine fibroid and possible clinical implications. Hum. Reprod. Update 2011, 17, 772-790. [CrossRef] 
27. Curtis, S.W.; Washburn, T.; Sewall, C.; Di Augustine, R.; Lindzey, J.; Couse, J.F.; Korach, K.S. Physiological coupling of growth factor and steroid receptor signaling pathways: Estrogen receptor knockout mice lack estrogen-like response to epidermal growth factor. Proc. Natl Acad Sci USA 1996, 93, 12626-12630. [CrossRef] [PubMed]

28. Nilsson, S.; Makela, S.; Treuter, E.; Tujague, M.; Thomsen, J.; Andersson, G.; Enmark, E.; Pettersson, K.; Warner, M.; Gustafsson, J.A. Mechanisms of estrogen action. Physiol. Rev. 2001, 81, 1535-1565. [CrossRef] [PubMed]

29. Andersen, J.; DyReyes, V.M.; Barbieri, R.L.; Coachman, D.M.; Miksicek, R.J. Leiomyoma primary cultures have elevated transcriptional response to estrogen compared with autologous myometrial cultures. J. Soc. Gynecol. Investig. 1995, 2, 542-551. [CrossRef]

30. Wei, J.; Chiriboga, L.; Mizuguchi, M.; Yee, H.; Mittal, K. Expression profile of tuberin and some potential tumorigenic factors in 60 patients with uterine leiomyomata. Mod. Pathol. 2005, 18, 179-188. [CrossRef]

31. Al-Hendy, A.; Diamond, M.P.; El-Sohemy, A.; Halder, S.K. 1,25-dihydroxyvitamin D3 regulates expression of sex steroid receptors in human uterine fibroid cells. J. Clin. Endocrinol. Metab. 2015, 100, E572-E582. [CrossRef] [PubMed]

32. Hassan, M.H.; Salama, S.A.; Arafa, H.M.; Hamada, F.M.; Al-Hendy, A. Adenovirus-mediated delivery of a dominant-negative estrogen receptor gene in uterine leiomyoma cells abrogates estrogen- and progesterone-regulated gene expression. J. Clin. Endocrinol. Metab. 2007, 92, 3949-3957. [CrossRef]

33. Hassan, M.H.; Salama, S.A.; Zhang, D.; Arafa, H.M.; Hamada, F.M.; Fouad, H.; Walker, C.C.; Al-Hendy, A. Gene therapy targeting leiomyoma: Adenovirus-mediated delivery of dominant-negative estrogen receptor gene shrinks uterine tumors in Eker rat model. Fertil. Steril. 2010, 93, 239-250. [CrossRef] [PubMed]

34. Kim, J.J.; Kurita, T.; Bulun, S.E. Progesterone action in endometrial cancer, endometriosis, uterine fibroids, and breast cancer. Endocr. Rev. 2013, 34, 130-162. [CrossRef] [PubMed]

35. Stewart, E.A.; Friedman, A.J.; Peck, K.; Nowak, R.A. Relative overexpression of collagen type I and collagen type III messenger ribonucleic acids by uterine leiomyomas during the proliferative phase of the menstrual cycle. J. Clin. Endocrinol. Metab. 1994, 79, 900-906. [CrossRef]

36. Leivonen, S.K.; Lazaridis, K.; Decock, J.; Chantry, A.; Edwards, D.R.; Kahari, V.M. Tgf-beta-elicited induction of tissue inhibitor of metalloproteinases (TIMP)-3 expression in fibroblasts involves complex interplay between smad3, p38alpha, and erk1/2. PLoS ONE 2013, 8, e57474. [CrossRef]

37. Arici, A.; Sozen, I. Transforming growth factor-beta3 is expressed at high levels in leiomyoma where it stimulates fibronectin expression and cell proliferation. Fertil. Steril. 2000, 73, 1006-1011. [CrossRef]

38. Islam, M.S.; Catherino, W.H.; Protic, O.; Janjusevic, M.; Gray, P.C.; Giannubilo, S.R.; Ciavattini, A.; Lamanna, P.; Tranquilli, A.L.; Petraglia, F.; et al. Role of activin-A and myostatin and their signaling pathway in human myometrial and leiomyoma cell function. J. Clin. Endocrinol Metab. 2014, 99, E775-E785. [CrossRef]

39. Protic, O.; Islam, M.S.; Greco, S.; Giannubilo, S.R.; Lamanna, P.; Petraglia, F.; Ciavattini, A.; Castellucci, M.; Hinz, B.; Ciarmela, P. Activin A in inflammation, tissue repair, and fibrosis: Possible role as inflammatory and fibrotic mediator of uterine fibroid development and growth. Semin. Reprod. Med. 2017, 35, 499-509. [CrossRef]

40. Tanwar, P.S.; Lee, H.J.; Zhang, L.; Zukerberg, L.R.; Taketo, M.M.; Rueda, B.R.; Teixeira, J.M. Constitutive activation of beta-catenin in uterine stroma and smooth muscle leads to the development of mesenchymal tumors in mice. Biol. Reprod. 2009, 81, 545-552. [CrossRef]

41. Ko, Y.A.; Jamaluddin, M.F.B.; Adebayo, M.; Bajwa, P.; Scott, R.J.; Dharmarajan, A.M.; Nahar, P.; Tanwar, P.S. Extracellular matrix (ECM) activates beta-catenin signaling in uterine fibroids. Reproduction 2018, 155, 61-71. [CrossRef] [PubMed]

42. Ono, M.; Yin, P.; Navarro, A.; Moravek, M.B.; Coon, J.S.T.; Druschitz, S.A.; Serna, V.A.; Qiang, W.; Brooks, D.C.; Malpani, S.S.; et al. Paracrine activation of Wnt/beta-catenin pathway in uterine leiomyoma stem cells promotes tumor growth. Proc. Natl Acad Sci USA 2013, 110, 17053-17058. [CrossRef] [PubMed]

43. Ono, M.; Yin, P.; Navarro, A.; Moravek, M.B.; Coon, V.J.; Druschitz, S.A.; Gottardi, C.J.; Bulun, S.E. Inhibition of canonical Wnt signaling attenuates human leiomyoma cell growth. Fertil. Steril. 2014, 101, 1441-1449. [CrossRef] [PubMed]

44. Al-Hendy, A.; Laknaur, A.; Diamond, M.P.; Ismail, N.; Boyer, T.G.; Halder, S.K. Silencing MED12 gene reduces proliferation of human leiomyoma cells mediated via Wnt/beta-catenin signaling pathway. Endocrinology 2017, 158, 592-603. [CrossRef] [PubMed] 
45. El Andaloussi, A.; Al-Hendy, A.; Ismail, N.; Boyer, T.G.; Halder, S.K. Introduction of somatic mutation in MED12 induces Wnt4/beta-catenin and disrupts autophagy in human uterine myometrial cell. Reprod. Sci. 2020, 27, 823-832. [CrossRef] [PubMed]

46. Ali, M.; Shahin, S.M.; Sabri, N.A.; Al-Hendy, A.; Yang, Q. Activation of beta-catenin signaling and its crosstalk with estrogen and histone deacetylases in human uterine fibroids. J. Clin. Endocrinol. Metab. 2020, 105. [CrossRef]

47. Lewis, T.D.; Malik, M.; Britten, J.; Parikh, T.; Cox, J.; Catherino, W.H. Ulipristal acetate decreases active tgf-beta3 and its canonical signaling in uterine leiomyoma via two novel mechanisms. Fertil. Steril. 2019, 111, 806-815e801. [CrossRef]

48. Vilos, G.A.; Allaire, C.; Laberge, P.Y.; Leyland, N.; Special, C. The management of uterine leiomyomas. J. Obstet. Gynaecol. Can. 2015, 37, 157-178. [CrossRef]

49. Ali, M.; Chaudhry, Z.T.; Al-Hendy, A. Successes and failures of uterine leiomyoma drug discovery. Expert Opin. Drug Discov. 2018, 13, 169-177. [CrossRef]

50. Schlaff, W.D.; Ackerman, R.T.; Al-Hendy, A.; Archer, D.F.; Barnhart, K.T.; Bradley, L.D.; Carr, B.R.; Feinberg, E.C.; Hurtado, S.M.; Kim, J.; et al. Elagolix for heavy menstrual bleeding in women with uterine fibroids. N Engl. J. Med. 2020, 382, 328-340. [CrossRef]

51. Steinauer, J.; Pritts, E.A.; Jackson, R.; Jacoby, A.F. Systematic review of mifepristone for the treatment of uterine leiomyomata. Obstet. Gynecol. 2004, 103, 1331-1336. [CrossRef] [PubMed]

52. Ali, M.; Al-Hendy, A. Selective progesterone receptor modulators for fertility preservation in women with symptomatic uterine fibroids. Biol. Reprod. 2017, 97, 337-352. [CrossRef] [PubMed]

53. Donnez, J.; Dolmans, M.M. Uterine fibroid management: From the present to the future. Hum. Reprod. Update 2016, 22, 665-686. [CrossRef] [PubMed]

54. Murji, A.; Whitaker, L.; Chow, T.L.; Sobel, M.L. Selective progesterone receptor modulators (sprms) for uterine fibroids. Cochrane Database Syst. Rev. 2017, 4, CD010770. [CrossRef] [PubMed]

55. Spitz, I.M. Clinical utility of progesterone receptor modulators and their effect on the endometrium. Curr. Opin. Obstet. Gynecol. 2009, 21, 318-324. [CrossRef] [PubMed]

56. Meunier, L.; Meszaros, M.; Pageaux, G.P.; Delay, J.M.; Herrero, A.; Pinzani, V.; Dominique, H.B. Acute liver failure requiring transplantation caused by ulipristal acetate. Clin. Res. Hepatol. Gastroenterol. 2020. [CrossRef] [PubMed]

57. Donnez, J.; Arriagada, P.; Marciniak, M.; Larrey, D. Liver safety parameters of ulipristal acetate for the treatment of uterine fibroids: A comprehensive review of the clinical development program. Expert Opin. Drug Saf. 2018, 17, 1225-1232. [CrossRef]

58. Ciebiera, M.; Vitale, S.G.; Ferrero, S.; Vilos, G.A.; Barra, F.; Caruso, S.; Lagana, A.S.; Sierant, A.; Cianci, A.; Jakiel, G. Vilaprisan, a new selective progesterone receptor modulator in uterine fibroid pharmacotherapy-will it really be a breakthrough? Curr. Pharm. Des. 2020, 26, 300-309. [CrossRef]

59. Holick, M.F. Vitamin D: A millenium perspective. J. Cell Biochem. 2003, 88, 296-307. [CrossRef]

60. Wetmore, J.B.; Kimber, C.; Mahnken, J.D.; Stubbs, J.R. Cholecalciferol v. Ergocalciferol for 25-hydroxyvitamin $\mathrm{D}(25(\mathrm{OH}) \mathrm{D})$ repletion in chronic kidney disease: A randomised clinical trial. Br. J. Nutr. 2016, 116, 2074-2081. [CrossRef]

61. Ciebiera, M.; Wlodarczyk, M.; Ciebiera, M.; Zareba, K.; Lukaszuk, K.; Jakiel, G. Vitamin D and uterine fibroids-review of the literature and novel concepts. Int. J. Mol. Sci. 2018, 19. [CrossRef] [PubMed]

62. Pludowski, P.; Holick, M.F.; Grant, W.B.; Konstantynowicz, J.; Mascarenhas, M.R.; Haq, A.; Povoroznyuk, V.; Balatska, N.; Barbosa, A.P.; Karonova, T.; et al. Vitamin D supplementation guidelines. J. Steroid Biochem. Mol. Biol. 2018, 175, 125-135. [CrossRef] [PubMed]

63. Brakta, S.; Diamond, J.S.; Al-Hendy, A.; Diamond, M.P.; Halder, S.K. Role of vitamin D in uterine fibroid biology. Fertil. Steril. 2015, 104, 698-706. [CrossRef] [PubMed]

64. Zhao, G.; Ford, E.S.; Tsai, J.; Li, C.; Croft, J.B. Factors associated with vitamin D deficiency and inadequacy among women of childbearing age in the United States. ISRN Obstet. Gynecol. 2012, 2012, 691486. [CrossRef] [PubMed]

65. Zadshir, A.; Tareen, N.; Pan, D.; Norris, K.; Martins, D. The prevalence of hypovitaminosis D among US adults: Data from the NHANES III. Ethn. Dis. 2005, 15, S5. [PubMed] 
66. Nesby-O'Dell, S.; Scanlon, K.S.; Cogswell, M.E.; Gillespie, C.; Hollis, B.W.; Looker, A.C.; Allen, C.; Doughertly, C.; Gunter, E.W.; Bowman, B.A. Hypovitaminosis D prevalence and determinants among african american and white women of reproductive age: Third national health and nutrition examination survey, 1988-1994. Am. J. Clin. Nutr. 2002, 76, 187-192. [CrossRef]

67. Sabry, M.; Halder, S.K.; Allah, A.S.; Roshdy, E.; Rajaratnam, V.; Al-Hendy, A. Serum vitamin D3 level inversely correlates with uterine fibroid volume in different ethnic groups: A cross-sectional observational study. Int. J. Womens Health 2013, 5, 93-100. [CrossRef]

68. Ciebiera, M.; Wlodarczyk, M.; Slabuszewska-Jozwiak, A.; Nowicka, G.; Jakiel, G. Influence of vitamin D and transforming growth factor beta3 serum concentrations, obesity, and family history on the risk for uterine fibroids. Fertil. Steril. 2016, 106, 1787-1792. [CrossRef]

69. Baird, D.D.; Hill, M.C.; Schectman, J.M.; Hollis, B.W. Vitamin D and the risk of uterine fibroids. Epidemiology 2013, 24, 447-453. [CrossRef]

70. Trump, D.L.; Aragon-Ching, J.B. Vitamin d in prostate cancer. Asian J. Androl. 2018, 20, 244-252. [CrossRef]

71. Mahendra, A.; Karishma; Choudhury, B.K.; Sharma, T.; Bansal, N.; Bansal, R.; Gupta, S. Vitamin d and gastrointestinal cancer. J. Lab. Physicians 2018, 10, 1-5. [CrossRef] [PubMed]

72. Welsh, J. Vitamin D and breast cancer: Past and present. J. Steroid Biochem. Mol. Biol. 2018, 177, 15-20. [CrossRef] [PubMed]

73. Sharan, C.; Halder, S.K.; Thota, C.; Jaleel, T.; Nair, S.; Al-Hendy, A. Vitamin D inhibits proliferation of human uterine leiomyoma cells via catechol-O-methyltransferase. Fertil. Steril. 2011, 95, 247-253. [CrossRef] [PubMed]

74. Halder, S.K.; Sharan, C.; Al-Hendy, A. 1,25-dihydroxyvitamin D3 treatment shrinks uterine leiomyoma tumors in the eker rat model. Biol. Reprod. 2012, 86, 116. [CrossRef] [PubMed]

75. Halder, S.K.; Sharan, C.; Al-Hendy, O.; Al-Hendy, A. Paricalcitol, a vitamin D receptor activator, inhibits tumor formation in a murine model of uterine fibroids. Reprod. Sci. 2014, 21, 1108-1119. [CrossRef] [PubMed]

76. Halder, S.K.; Goodwin, J.S.; Al-Hendy, A. 1,25-dihydroxyvitamin D3 reduces tgf-beta3-induced fibrosis-related gene expression in human uterine leiomyoma cells. J. Clin. Endocrinol. Metab. 2011, 96, E754-E762. [CrossRef]

77. Halder, S.K.; Osteen, K.G.; Al-Hendy, A. Vitamin D3 inhibits expression and activities of matrix metalloproteinase-2 and -9 in human uterine fibroid cells. Hum. Reprod. 2013, 28, 2407-2416. [CrossRef]

78. Halder, S.K.; Osteen, K.G.; Al-Hendy, A. 1,25-dihydroxyvitamin D3 reduces extracellular matrix-associated protein expression in human uterine fibroid cells. Biol. Reprod. 2013, 89, 150. [CrossRef]

79. Corachan, A.; Ferrero, H.; Escrig, J.; Monleon, J.; Faus, A.; Cervello, I.; Pellicer, A. Long-term vitamin d treatment decreases human uterine leiomyoma size in a xenograft animal model. Fertil. Steril. 2020, 113, 205-216e204. [CrossRef]

80. Ciavattini, A.; Delli Carpini, G.; Serri, M.; Vignini, A.; Sabbatinelli, J.; Tozzi, A.; Aggiusti, A.; Clemente, N. Hypovitaminosis D and "small burden" uterine fibroids: Opportunity for a vitamin D supplementation. Medicine (Baltimore) 2016, 95, e5698. [CrossRef]

81. Porcaro, G.; Santamaria, A.; Giordano, D.; Angelozzi, P. Vitamin D plus epigallocatechin gallate: A novel promising approach for uterine myomas. Eur. Rev. Med. Pharmacol. Sci. 2020, 24, 3344-3351. [CrossRef] [PubMed]

82. Ali, M.; Shahin, S.M.; Sabri, N.A.; Al-Hendy, A.; Yang, Q. 1,25 dihydroxyvitamin D3 enhances the antifibroid effects of ulipristal acetate in human uterine fibroids. Reprod. Sci. 2019, 26, 812-828. [CrossRef] [PubMed]

83. Ciebiera, M.; Meczekalski, B.; Lukaszuk, K.; Jakiel, G. Potential synergism between ulipristal acetate and vitamin D3 in uterine fibroid pharmacotherapy - 2 case studies. Gynecol. Endocrinol. 2019, 35, 473-477. [CrossRef] [PubMed]

84. Arjeh, S.; Darsareh, F.; Asl, Z.A.; Kutenaei, M.A. Effect of oral consumption of vitamin d on uterine fibroids: A randomized clinical trial. Complement. Ther. Clin. Pract. 2020, 39, 101159. [CrossRef] [PubMed]

85. Prasanth, M.I.; Sivamaruthi, B.S.; Chaiyasut, C.; Tencomnao, T. A review of the role of green tea (Camellia sinensis) in antiphotoaging, stress resistance, neuroprotection, and autophagy. Nutrients 2019, 11. [CrossRef] [PubMed]

86. Zhang, D.; Al-Hendy, M.; Richard-Davis, G.; Montgomery-Rice, V.; Sharan, C.; Rajaratnam, V.; Khurana, A.; Al-Hendy, A. Green tea extract inhibits proliferation of uterine leiomyoma cells in vitro and in nude mice. Am. J. Obstet. Gynecol. 2010, 202, 289.e1-289.e9. [CrossRef] 
87. Graham, H.N. Green tea composition, consumption, and polyphenol chemistry. Prev. Med. 1992, 21, 334-350. [CrossRef]

88. Lin, J.K.; Liang, Y.C.; Lin-Shiau, S.Y. Cancer chemoprevention by tea polyphenols through mitotic signal transduction blockade. Biochem. Pharmacol. 1999, 58, 911-915. [CrossRef]

89. Chow, H.H.; Cai, Y.; Hakim, I.A.; Crowell, J.A.; Shahi, F.; Brooks, C.A.; Dorr, R.T.; Hara, Y.; Alberts, D.S. Pharmacokinetics and safety of green tea polyphenols after multiple-dose administration of epigallocatechin gallate and polyphenon e in healthy individuals. Clin. Cancer Res. 2003, 9, 3312-3319.

90. Thangapazham, R.L.; Singh, A.K.; Sharma, A.; Warren, J.; Gaddipati, J.P.; Maheshwari, R.K. Green tea polyphenols and its constituent epigallocatechin gallate inhibits proliferation of human breast cancer cells in vitro and in vivo. Cancer Lett. 2007, 245, 232-241. [CrossRef]

91. Tang, Y.; Zhao, D.Y.; Elliott, S.; Zhao, W.; Curiel, T.J.; Beckman, B.S.; Burow, M.E. Epigallocatechin-3 gallate induces growth inhibition and apoptosis in human breast cancer cells through survivin suppression. Int. J. Oncol. 2007, 31, 705-711. [CrossRef] [PubMed]

92. Liang, Y.C.; Lin-Shiau, S.Y.; Chen, C.F.; Lin, J.K. Inhibition of cyclin-dependent kinases 2 and 4 activities as well as induction of cdk inhibitors p21 and p27 during growth arrest of human breast carcinoma cells by (-)-epigallocatechin-3-gallate. J. Cell Biochem. 1999, 75, 1-12. [CrossRef]

93. Chuang, T.Y.; Min, J.; Wu, H.L.; McCrary, C.; Layman, L.C.; Diamond, M.P.; Azziz, R.; Al-Hendy, A.; Chen, Y.H. Berberine inhibits uterine leiomyoma cell proliferation via downregulation of cyclooxygenase 2 and pituitary tumor-transforming gene 1. Reprod. Sci. 2017, 24, 1005-1013. [CrossRef]

94. Gupta, S.; Ahmad, N.; Nieminen, A.L.; Mukhtar, H. Growth inhibition, cell-cycle dysregulation, and induction of apoptosis by green tea constituent (-)-epigallocatechin-3-gallate in androgen-sensitive and androgen-insensitive human prostate carcinoma cells. Toxicol. Appl. Pharmacol. 2000, 164, 82-90. [CrossRef] [PubMed]

95. Jung, Y.D.; Kim, M.S.; Shin, B.A.; Chay, K.O.; Ahn, B.W.; Liu, W.; Bucana, C.D.; Gallick, G.E.; Ellis, L.M. EGCG, a major component of green tea, inhibits tumour growth by inhibiting VEGF induction in human colon carcinoma cells. Br. J. Cancer 2001, 84, 844-850. [CrossRef]

96. Demeule, M.; Brossard, M.; Page, M.; Gingras, D.; Beliveau, R. Matrix metalloproteinase inhibition by green tea catechins. Biochim Biophys Acta 2000, 1478, 51-60. [CrossRef]

97. Ozercan, I.H.; Sahin, N.; Akdemir, F.; Onderci, M.; Seren, S.; Sahin, K.; Kucuk, O. Chemoprevention of fibroid tumors by [-]-epigallocatechin-3-gallate in quail. Nutr. Res. 2008, 28, 92-97. [CrossRef]

98. Zhang, D.; Al-Hendy, M.; Richard-Davis, G.; Montgomery-Rice, V.; Rajaratnam, V.; Al-Hendy, A. Antiproliferative and proapoptotic effects of epigallocatechin gallate on human leiomyoma cells. Fertil. Steril. 2010, 94, 1887-1893. [CrossRef]

99. Ahmad, N.; Gupta, S.; Mukhtar, H. Green tea polyphenol epigallocatechin-3-gallate differentially modulates nuclear factor kappa beta in cancer cells versus normal cells. Arch. Biochem. Biophys. 2000, 376, 338-346. [CrossRef]

100. Beck, S.E.; Jung, B.H.; Fiorino, A.; Gomez, J.; Rosario, E.D.; Cabrera, B.L.; Huang, S.C.; Chow, J.Y.; Carethers, J.M. Bone morphogenetic protein signaling and growth suppression in colon cancer. Am. J. Physiol. Gastrointest. Liver Physiol. 2006, 291, G135-G145. [CrossRef]

101. Horvath, L.G.; Henshall, S.M.; Kench, J.G.; Turner, J.J.; Golovsky, D.; Brenner, P.C.; O’Neill, G.F.; Kooner, R.; Stricker, P.D.; Grygiel, J.J.; et al. Loss of BMP2, Smad8, and Smad4 expression in prostate cancer progression. Prostate 2004, 59, 234-242. [CrossRef]

102. Al-Hendy, A.; Salama, S.A. Catechol-O-methyltransferase polymorphism is associated with increased uterine leiomyoma risk in different ethnic groups. J. Soc. Gynecol. Investig. 2006, 13, 136-144. [CrossRef]

103. Salama, S.A.; Ho, S.L.; Wang, H.Q.; Tenhunen, J.; Tilgmann, C.; Al-Hendy, A. Hormonal regulation of catechol-o-methyl transferase activity in women with uterine leiomyomas. Fertil. Steril. 2006, 86, $259-262$. [CrossRef]

104. Othman, E.E.; Al-Hendy, A. Molecular genetics and racial disparities of uterine leiomyomas. Best Pract. Res. Clin. Obstet. Gynaecol. 2008, 22, 589-601. [CrossRef]

105. Zhu, B.T.; Shim, J.Y.; Nagai, M.; Bai, H.W. Molecular modelling study of the mechanism of high-potency inhibition of human catechol-O-methyltransferase by (-)-epigallocatechin-3-o-gallate. Xenobiotica 2008, 38, 130-146. [CrossRef] 
106. Roshdy, E.; Rajaratnam, V.; Maitra, S.; Sabry, M.; Allah, A.S.; Al-Hendy, A. Treatment of symptomatic uterine fibroids with green tea extract: A pilot randomized controlled clinical study. Int. J. Womens Health 2013, 5, 477-486. [CrossRef]

107. Ahmed, R.S.; Liu, G.; Renzetti, A.; Farshi, P.; Yang, H.; Soave, C.; Saed, G.; El-Ghoneimy, A.A.; El-Banna, H.A.; Foldes, R.; et al. Biological and mechanistic characterization of novel prodrugs of green tea polyphenol epigallocatechin gallate analogs in human leiomyoma cell lines. J. Cell Biochem. 2016, 117, 2357-2369. [CrossRef]

108. Wang, N.; Tan, H.Y.; Li, L.; Yuen, M.F.; Feng, Y. Berberine and coptidis rhizoma as potential anticancer agents: Recent updates and future perspectives. J. Ethnopharmacol. 2015, 176, 35-48. [CrossRef]

109. Lee, T.K.; Kim, D.I.; Song, Y.L.; Lee, Y.C.; Kim, H.M.; Kim, C.H. Differential inhibition of Scutellaria barbata D. Don (Lamiaceae) on HCG-promoted proliferation of cultured uterine leiomyomal and myometrial smooth muscle cells. Immunopharmacol. Immunotoxicol. 2004, 26, 329-342. [CrossRef] [PubMed]

110. Sun, Y.; Xun, K.; Wang, Y.; Chen, X. A systematic review of the anticancer properties of berberine, a natural product from chinese herbs. Anticancer Drugs 2009, 20, 757-769. [CrossRef]

111. Fu, L.; Chen, W.; Guo, W.; Wang, J.; Tian, Y.; Shi, D.; Zhang, X.; Qiu, H.; Xiao, X.; Kang, T.; et al. Berberine targets AP-2/hTERT, NF-kappaB/COX-2, HIF-1alpha/VEGF and cytochrome-C/caspase signaling to suppress human cancer cell growth. PLoS ONE 2013, 8, e69240. [CrossRef]

112. Lee, T.K.; Kim, D.I.; Han, J.Y.; Kim, C.H. Inhibitory effects of Scutellaria barbata D. Don. and Euonymus Alatus Sieb. On aromatase activity of human leiomyomal cells. Immunopharmacol. Immunotoxicol. 2004, 26, 315-327. [CrossRef] [PubMed]

113. Wu, H.L.; Chuang, T.Y.; Al-Hendy, A.; Diamond, M.P.; Azziz, R.; Chen, Y.H. Berberine inhibits the proliferation of human uterine leiomyoma cells. Fertil. Steril. 2015, 103, 1098-1106. [CrossRef] [PubMed]

114. Tsai, S.J.; Lin, S.J.; Cheng, Y.M.; Chen, H.M.; Wing, L.Y. Expression and functional analysis of pituitary tumor transforming gene-1 in uterine leiomyomas. J. Clin. Endocrinol. Metab. 2005, 90, 3715-3723. [CrossRef] [PubMed]

115. Park, S.B.; Jee, B.C.; Kim, S.H.; Cho, Y.J.; Han, M. Cyclooxygenase-2 inhibitor, celecoxib, inhibits leiomyoma cell proliferation through the nuclear factor kappaB pathway. Reprod. Sci. 2014, 21, 1187-1195. [CrossRef] [PubMed]

116. Ke, X.; Dou, F.; Cheng, Z.; Dai, H.; Zhang, W.; Qu, X.; Ding, P.; Zuo, X. High expression of cyclooxygenase-2 in uterine fibroids and its correlation with cell proliferation. Eur. J. Obstet. Gynecol. Reprod. Biol. 2013, 168, 199-203. [CrossRef] [PubMed]

117. Hewlings, S.J.; Kalman, D.S. Curcumin: A review of its' effects on human health. Foods 2017, 6. [CrossRef]

118. Cheng, I.C.; Li, R.K.; Leung, G.P.; Li, S.L.; Kong, M.; Lao, L.X.; Zhang, Z.J.; Lin, W.L.; Ng, E.H.; Rong, J.H.; et al. Application of UPLC-MS/MS to simultaneously detect four bioactive compounds in the tumour-shrinking decoction (FM1523) for uterine fibroids treatment. Phytochem. Anal. 2019, 30, 447-455. [CrossRef]

119. Bajracharya, P.; Lee, E.J.; Lee, D.M.; Shim, S.H.; Kim, K.J.; Lee, S.H.; Bae, J.J.; Chun, S.S.; Lee, T.K.; Kwon, S.H.; et al. Effect of different ingredients in traditional korean medicine for human uterine leiomyoma on normal myometrial and leiomyomal smooth muscle cell proliferation. Arch. Pharm. Res. 2009, 32, 1555-1563. [CrossRef]

120. Chen, X.; Chen, X.; Shi, X.; Gao, Z.; Guo, Z. Curcumin attenuates endothelial cell fibrosis through inhibiting endothelial-interstitial transformation. Clin. Exp. Pharmacol. Physiol. 2020. [CrossRef]

121. Malik, M.; Mendoza, M.; Payson, M.; Catherino, W.H. Curcumin, a nutritional supplement with antineoplastic activity, enhances leiomyoma cell apoptosis and decreases fibronectin expression. Fertil Steril 2009, 91, 2177-2184. [CrossRef] [PubMed]

122. Tsuiji, K.; Takeda, T.; Li, B.; Wakabayashi, A.; Kondo, A.; Kimura, T.; Yaegashi, N. Inhibitory effect of curcumin on uterine leiomyoma cell proliferation. Gynecol. Endocrinol. 2011, 27, 512-517. [CrossRef] [PubMed]

123. Yu, C.H.; Zhao, J.S.; Zhao, H.; Peng, T.; Shen, D.C.; Xu, Q.X.; Li, Y.; Webb, R.C.; Wang, M.H.; Shi, X.M.; et al. Transcriptional profiling of uterine leiomyoma rats treated by a traditional herb pair, Curcumae rhizoma and Sparganii rhizoma. Braz. J. Med. Biol. Res. 2019, 52, e8132. [CrossRef] [PubMed]

124. Biswas, S.; Chen, S.; Liang, G.; Feng, B.; Cai, L.; Khan, Z.A.; Chakrabarti, S. Curcumin analogs reduce stress and inflammation indices in experimental models of diabetes. Front. Endocrinol. (Lausanne) 2019, 10, 887. [CrossRef] [PubMed] 
125. Feng, T.; Wei, Y.; Lee, R.J.; Zhao, L. Liposomal curcumin and its application in cancer. Int. J. Nanomedicine 2017, 12, 6027-6044. [CrossRef]

126. Salehi, B.; Mishra, A.P.; Nigam, M.; Sener, B.; Kilic, M.; Sharifi-Rad, M.; Fokou, P.V.T.; Martins, N.; Sharifi-Rad, J. Resveratrol: A double-edged sword in health benefits. Biomedicines 2018, 6. [CrossRef]

127. Bhullar, K.S.; Hubbard, B.P. Lifespan and healthspan extension by resveratrol. Biochim. Biophys. Acta 2015, 1852, 1209-1218. [CrossRef]

128. Li, L.; Qiu, R.L.; Lin, Y.; Cai, Y.; Bian, Y.; Fan, Y.; Gao, X.J. Resveratrol suppresses human cervical carcinoma cell proliferation and elevates apoptosis via the mitochondrial and p53 signaling pathways. Oncol. Lett. 2018, 15, 9845-9851. [CrossRef]

129. Zhou, Z.X.; Mou, S.F.; Chen, X.Q.; Gong, L.L.; Ge, W.S. Anti-inflammatory activity of resveratrol prevents inflammation by inhibiting NFkappaB in animal models of acute pharyngitis. Mol. Med. Rep. 2018, 17, 1269-1274. [CrossRef]

130. Kim, D.I.; Lee, T.K.; Lim, I.S.; Kim, H.; Lee, Y.C.; Kim, C.H. Regulation of IGF-1 production and proliferation of human leiomyomal smooth muscle cells by Scutellaria barbata D. Don in vitro: Isolation of flavonoids of apigenin and luteolin as acting compounds. Toxicol. Appl. Pharmacol. 2005, 205, 213-224. [CrossRef]

131. Wu, C.H.; Shieh, T.M.; Wei, L.H.; Cheng, T.F.; Chen, H.Y.; Huang, T.C.; Wang, K.L.; Hsia, S.M. Resveratrol inhibits proliferation of myometrial and leiomyoma cells and decreases extracellular matrix-associated protein expression. J. Funct. Foods 2016, 23, 241-252. [CrossRef]

132. Ho, Y.; Sh Yang, Y.C.; Chin, Y.T.; Chou, S.Y.; Chen, Y.R.; Shih, Y.J.; Whang-Peng, J.; Changou, C.A.; Liu, H.L.; Lin, S.J.; et al. Resveratrol inhibits human leiomyoma cell proliferation via crosstalk between integrin alphavbeta3 and IGF-1R. Food Chem. Toxicol. 2018, 120, 346-355. [CrossRef]

133. Chen, H.Y.; Lin, P.H.; Shih, Y.H.; Wang, K.L.; Hong, Y.H.; Shieh, T.M.; Huang, T.C.; Hsia, S.M. Natural antioxidant resveratrol suppresses uterine fibroid cell growth and extracellular matrix formation in vitro and in vivo. Antioxidants 2019, 8. [CrossRef] [PubMed]

134. Collins, K.G.; Fitzgerald, G.F.; Stanton, C.; Ross, R.P. Looking beyond the terrestrial: The potential of seaweed derived bioactives to treat non-communicable diseases. Mar. Drugs 2016, 14. [CrossRef] [PubMed]

135. Charboneau, A.J.; Delaney, J.P.; Beilman, G. Fucoidans inhibit the formation of post-operative abdominal adhesions in a rat model. PLoS ONE 2018, 13, e0207797. [CrossRef] [PubMed]

136. Li, X.; Wu, N.; Chen, Y.; Tan, J.; Wang, J.; Geng, L.; Qin, Y.; Zhang, Q. Degradation of different molecular weight fucoidans and their inhibition of tgf-beta1 induced epithelial-mesenchymal transition in mouse renal tubular epithelial cells. Int. J. Biol. Macromol. 2020, 151, 545-553. [CrossRef]

137. Wang, L.; Zhang, P.; Li, X.; Zhang, Y.; Zhan, Q.; Wang, C. Low-molecular-weight fucoidan attenuates bleomycin-induced pulmonary fibrosis: Possible role in inhibiting tgf-beta1-induced epithelial-mesenchymal transition through ERK pathway. Am. J. Transl. Res. 2019, 11, 2590-2602.

138. Wu, S.Y.; Chen, Y.T.; Tsai, G.Y.; Hsu, F.Y.; Hwang, P.A. Protective effect of low-molecular-weight fucoidan on radiation-induced fibrosis through tgf-beta1/Smad pathway-mediated inhibition of collagen $\mathrm{i}$ accumulation. Mar. Drugs 2020, 18. [CrossRef]

139. Chen, H.Y.; Huang, T.C.; Lin, L.C.; Shieh, T.M.; Wu, C.H.; Wang, K.L.; Hong, Y.H.; Hsia, S.M. Fucoidan inhibits the proliferation of leiomyoma cells and decreases extracellular matrix-associated protein expression. Cell Physiol. Biochem. 2018, 49, 1970-1986. [CrossRef]

140. Licznerska, B.; Baer-Dubowska, W. Indole-3-carbinol and its role in chronic diseases. Adv. Exp. Med. Biol. 2016, 928, 131-154. [CrossRef]

141. Ahmad, A.; Biersack, B.; Li, Y.; Kong, D.; Bao, B.; Schobert, R.; Padhye, S.B.; Sarkar, F.H. Targeted regulation of PI3K/Akt/mTOR/NF-kappaB signaling by indole compounds and their derivatives: Mechanistic details and biological implications for cancer therapy. Anticancer Agents Med. Chem. 2013, 13, 1002-1013. [CrossRef] [PubMed]

142. Li, B.; Cong, M.; Zhu, Y.; Xiong, Y.; Jin, W.; Wan, Y.; Zhou, Y.; Ao, Y.; Wang, H. Indole-3-carbinol induces apoptosis of hepatic stellate cells through K63 de-ubiquitination of RIP1 in rats. Cell Physiol. Biochem. 2017, 41, 1481-1490. [CrossRef] [PubMed]

143. Greco, S.; Islam, M.S.; Zannotti, A.; Delli Carpini, G.; Giannubilo, S.R.; Ciavattini, A.; Petraglia, F.; Ciarmela, P. Quercetin and indole-3-carbinol inhibit extracellular matrix expression in human primary uterine leiomyoma cells. Reprod. Biomed. Online 2020. [CrossRef] [PubMed] 
144. Cho, S.; Kim, S.; Jin, Z.; Yang, H.; Han, D.; Baek, N.I.; Jo, J.; Cho, C.W.; Park, J.H.; Shimizu, M.; et al. Isoliquiritigenin, a chalcone compound, is a positive allosteric modulator of GABAA receptors and shows hypnotic effects. Biochem. Biophys. Res. Commun. 2011, 413, 637-642. [CrossRef]

145. Park, S.J.; Song, H.Y.; Youn, H.S. Suppression of the TRIF-dependent signaling pathway of toll-like receptors by isoliquiritigenin in RAW264.7 macrophages. Mol. Cells 2009, 28, 365-368. [CrossRef]

146. Feldman, M.; Santos, J.; Grenier, D. Comparative evaluation of two structurally related flavonoids, isoliquiritigenin and liquiritigenin, for their oral infection therapeutic potential. J. Nat. Prod. 2011, 74, 1862-1867. [CrossRef]

147. Watanabe, Y.; Nagai, Y.; Honda, H.; Okamoto, N.; Yamamoto, S.; Hamashima, T.; Ishii, Y.; Tanaka, M.; Suganami, T.; Sasahara, M.; et al. Isoliquiritigenin attenuates adipose tissue inflammation in vitro and adipose tissue fibrosis through inhibition of innate immune responses in mice. Sci. Rep. 2016, 6, 23097. [CrossRef]

148. Xiang, S.; Chen, H.; Luo, X.; An, B.; Wu, W.; Cao, S.; Ruan, S.; Wang, Z.; Weng, L.; Zhu, H.; et al. Isoliquiritigenin suppresses human melanoma growth by targeting miR-301b/LRIG1 signaling. J. Exp. Clin. Cancer Res. 2018, 37, 184. [CrossRef]

149. Li, J.; Kang, S.W.; Kim, J.L.; Sung, H.Y.; Kwun, I.S.; Kang, Y.H. Isoliquiritigenin entails blockade of tgf-beta1-Smad signaling for retarding high glucose-induced mesangial matrix accumulation. J. Agric. Food Chem. 2010, 58, 3205-3212. [CrossRef]

150. Kim, D.C.; Ramachandran, S.; Baek, S.H.; Kwon, S.H.; Kwon, K.Y.; Cha, S.D.; Bae, I.; Cho, C.H. Induction of growth inhibition and apoptosis in human uterine leiomyoma cells by isoliquiritigenin. Reprod. Sci. 2008, 15, 552-558. [CrossRef]

151. Lin, P.H.; Kung, H.L.; Chen, H.Y.; Huang, K.C.; Hsia, S.M. Isoliquiritigenin suppresses E2-induced uterine leiomyoma growth through the modulation of cell death program and the repression of ecm accumulation. Cancers 2019, 11. [CrossRef] [PubMed]

152. Formica, J.V.; Regelson, W. Review of the biology of quercetin and related bioflavonoids. Food Chem. Toxicol. 1995, 33, 1061-1080. [CrossRef]

153. Andres, S.; Pevny, S.; Ziegenhagen, R.; Bakhiya, N.; Schafer, B.; Hirsch-Ernst, K.I.; Lampen, A. Safety aspects of the use of quercetin as a dietary supplement. Mol. Nutr. Food Res. 2018, 62. [CrossRef]

154. Murakami, A.; Ashida, H.; Terao, J. Multitargeted cancer prevention by quercetin. Cancer Lett. 2008, 269, 315-325. [CrossRef] [PubMed]

155. Van der Woude, H.; Ter Veld, M.G.; Jacobs, N.; van der Saag, P.T.; Murk, A.J.; Rietjens, I.M. The stimulation of cell proliferation by quercetin is mediated by the estrogen receptor. Mol. Nutr. Food Res. 2005, 49, 763-771. [CrossRef]

156. Ganbold, M.; Shimamoto, Y.; Ferdousi, F.; Tominaga, K.; Isoda, H. Antifibrotic effect of methylated quercetin derivatives on tgfbeta-induced hepatic stellate cells. Biochem. Biophys. Rep. 2019, 20, 100678. [CrossRef]

157. Xiao, Y.; Zhou, L.; Zhang, T.; Qin, C.; Wei, P.; Luo, L.; Luo, L.; Huang, G.; Chen, A.; Liu, G. Anti-fibrosis activity of quercetin attenuates rabbit tracheal stenosis via the tgf-beta/Akt/mTOR signaling pathway. Life Sci. 2020, 250, 117552. [CrossRef]

158. Cavalcante, M.B.; Saccon, T.D.; Nunes, A.D.C.; Kirkland, J.L.; Tchkonia, T.; Schneider, A.; Masternak, M.M. Dasatinib plus quercetin prevents uterine age-related dysfunction and fibrosis in mice. Aging (Albany NY) 2020, 12, 2711-2722. [CrossRef]

159. Borahay, M.A.; Asoglu, M.R.; Mas, A.; Adam, S.; Kilic, G.S.; Al-Hendy, A. Estrogen receptors and signaling in fibroids: Role in pathobiology and therapeutic implications. Reprod. Sci. 2017, 24, 1235-1244. [CrossRef]

160. Houghton, C.A.; Fassett, R.G.; Coombes, J.S. Sulforaphane: Translational research from laboratory bench to clinic. Nutr. Rev. 2013, 71, 709-726. [CrossRef]

161. Fix, C.; Carver-Molina, A.; Chakrabarti, M.; Azhar, M.; Carver, W. Effects of the isothiocyanate sulforaphane on tgf-beta1-induced rat cardiac fibroblast activation and extracellular matrix interactions. J. Cell Physiol. 2019, 234, 13931-13941. [CrossRef]

162. Milito, A.; Brancaccio, M.; D’Argenio, G.; Castellano, I. Natural sulfur-containing compounds: An alternative therapeutic strategy against liver fibrosis. Cells 2019, 8. [CrossRef] [PubMed]

163. Oh, C.J.; Kim, J.Y.; Min, A.K.; Park, K.G.; Harris, R.A.; Kim, H.J.; Lee, I.K. Sulforaphane attenuates hepatic fibrosis via NF-E2-related factor 2-mediated inhibition of transforming growth factor-beta/Smad signaling. Free Radic. Biol. Med. 2012, 52, 671-682. [CrossRef] [PubMed] 
164. Kyung, S.Y.; Kim, D.Y.; Yoon, J.Y.; Son, E.S.; Kim, Y.J.; Park, J.W.; Jeong, S.H. Sulforaphane attenuates pulmonary fibrosis by inhibiting the epithelial-mesenchymal transition. BMC Pharmacol. Toxicol. 2018, 19, 13. [CrossRef] [PubMed]

165. Sun, C.; Li, S.; Li, D. Sulforaphane mitigates muscle fibrosis in mdx mice via Nrf2-mediated inhibition of TGF-beta/smad signaling. J. Appl. Physiol. 2016, 120, 377-390. [CrossRef] [PubMed]

166. Islam, M.S.; Afrin., S.; Brennan, J.; Segars, J. The active phytochemical of cruciferous vegetables, sulforaphane, reduces proliferation and inflammation of uterine fibroid cells. In Meeting: The Basic Science of Uterine Fibroids; NC, 27701. 28/FEB/2020; National Institute of Environmental Health Sciences: Research Triangle Park, CA, USA.

167. Lila, M.A.; Burton-Freeman, B.; Grace, M.; Kalt, W. Unraveling anthocyanin bioavailability for human health. Annu. Rev. Food Sci. Technol. 2016, 7, 375-393. [CrossRef] [PubMed]

168. Islam, M.S.; Giampieri, F.; Janjusevic, M.; Gasparrini, M.; Forbes-Hernandez, T.Y.; Mazzoni, L.; Greco, S.; Giannubilo, S.R.; Ciavattini, A.; Mezzetti, B.; et al. An anthocyanin rich strawberry extract induces apoptosis and ROS while decreases glycolysis and fibrosis in human uterine leiomyoma cells. Oncotarget 2017, 8 , 23575-23587. [CrossRef]

169. Giampieri, F.; Islam, M.S.; Greco, S.; Gasparrini, M.; Forbes Hernandez, T.Y.; Delli Carpini, G.; Giannubilo, S.R.; Ciavattini, A.; Mezzetti, B.; Mazzoni, L.; et al. Romina: A powerful strawberry with in vitro efficacy against uterine leiomyoma cells. J. Cell Physiol. 2019, 234, 7622-7633. [CrossRef]

170. Giampieri, F.; Tulipani, S.; Alvarez-Suarez, J.M.; Quiles, J.L.; Mezzetti, B.; Battino, M. The strawberry: Composition, nutritional quality, and impact on human health. Nutrition 2012, 28, 9-19. [CrossRef]

171. Wang, S.Y.; Feng, R.; Lu, Y.; Bowman, L.; Ding, M. Inhibitory effect on activator protein-1, nuclear factor-kappaB, and cell transformation by extracts of strawberries (Fragaria x ananassa duch.). J. Agric. Food Chem. 2005, 53, 4187-4193. [CrossRef]

172. Sokola-Wysoczanska, E.; Wysoczanski, T.; Wagner,J.; Czyz, K.; Bodkowski, R.; Lochynski, S.; Patkowska-Sokola, B. Polyunsaturated fatty acids and their potential therapeutic role in cardiovascular system disorders-a review. Nutrients 2018, 10. [CrossRef] [PubMed]

173. Ibarguren, M.; Lopez, D.J.; Escriba, P.V. The effect of natural and synthetic fatty acids on membrane structure, microdomain organization, cellular functions and human health. Biochim. Biophys. Acta 2014, 1838, 1518-1528. [CrossRef] [PubMed]

174. Rizos, E.C.; Ntzani, E.E.; Bika, E.; Kostapanos, M.S.; Elisaf, M.S. Association between omega-3 fatty acid supplementation and risk of major cardiovascular disease events: A systematic review and meta-analysis. JAMA 2012, 308, 1024-1033. [CrossRef] [PubMed]

175. Calder, P.C.; Grimble, R.F. Polyunsaturated fatty acids, inflammation and immunity. Eur. J. Clin. Nutr. 2002, 56 (Suppl. 3), S14-S19. [CrossRef]

176. Li, K.; Huang, T.; Zheng, J.; Wu, K.; Li, D. Effect of marine-derived n-3 polyunsaturated fatty acids on c-reactive protein, interleukin 6 and tumor necrosis factor alpha: A meta-analysis. PLoS ONE 2014, 9, e88103. [CrossRef]

177. Islam, M.S.; Castellucci, C.; Fiorini, R.; Greco, S.; Gagliardi, R.; Zannotti, A.; Giannubilo, S.R.; Ciavattini, A.; Frega, N.G.; Pacetti, D.; et al. Omega-3 fatty acids modulate the lipid profile, membrane architecture, and gene expression of leiomyoma cells. J. Cell Physiol. 2018, 233, 7143-7156. [CrossRef]

178. Baldwin, I.T. Jasmonate-induced responses are costly but benefit plants under attack in native populations. Proc. Natl. Acad. Sci. USA 1998, 95, 8113-8118. [CrossRef]

179. Wasternack, C. Jasmonates: An update on biosynthesis, signal transduction and action in plant stress response, growth and development. Ann. Bot. 2007, 100, 681-697. [CrossRef]

180. Gunjegaonkar, S.M.; Shanmugarajan, T.S. Molecular mechanism of plant stress hormone methyl jasmonate for its anti-inflammatory activity. Plant. Signal. Behav. 2019, 14, e1642038. [CrossRef]

181. Cesari, I.M.; Carvalho, E.; Figueiredo Rodrigues, M.; Mendonca Bdos, S.; Amoedo, N.D.; Rumjanek, F.D. Methyl jasmonate: Putative mechanisms of action on cancer cells cycle, metabolism, and apoptosis. Int. J. Cell Biol. 2014, 2014, 572097. [CrossRef]

182. Sa-Nakanishi, A.B.; Soni-Neto, J.; Moreira, L.S.; Goncalves, G.A.; Silva, F.M.S.; Bracht, L.; Bersani-Amado, C.A.; Peralta, R.M.; Bracht, A.; Comar, J.F. Anti-inflammatory and antioxidant actions of methyl jasmonate are associated with metabolic modifications in the liver of arthritic rats. Oxid. Med. Cell Longev. 2018, 2018, 2056250. [CrossRef] [PubMed] 
183. Umukoro, S.; Alabi, A.O.; Eduviere, A.T.; Ajayi, A.M.; Oluwole, O.G. Anti-inflammatory and membrane stabilizing properties of methyl jasmonate in rats. Chin. J. Nat. Med. 2017, 15, 202-209. [CrossRef]

184. Pereira-Marostica, H.V.; Castro, L.S.; Goncalves, G.A.; Silva, F.M.S.; Bracht, L.; Bersani-Amado, C.A.; Peralta, R.M.; Comar, J.F.; Bracht, A.; Sa-Nakanishi, A.B. Methyl jasmonate reduces inflammation and oxidative stress in the brain of arthritic rats. Antioxidants 2019, 8. [CrossRef] [PubMed]

185. Ribera-Fonseca, A.; Jimenez, D.; Leal, P.; Riquelme, I.; Roa, J.C.; Alberdi, M.; Peek, R.M.; Reyes-Diaz, M. The anti-proliferative and anti-invasive effect of leaf extracts of blueberry plants treated with methyl jasmonate on human gastric cancer in vitro is related to their antioxidant properties. Antioxidants 2020, 9. [CrossRef]

186. Ali, M.; Al-Hendy, A.; Yang, Q. Natural compound methyl jasmonate shows promising anti-fibroid effects via inhibition of EZH2 mediated $\mathrm{Wnt} / \beta$-catenin signaling pathway activation in human uterine fibroids. In Meeting: The Basic Science of Uterine Fibroids; NC, 27701. 28/FEB/2020; National Institute of Environmental Health Sciences: Research Triangle Park, CA, USA.

187. Vire, E.; Brenner, C.; Deplus, R.; Blanchon, L.; Fraga, M.; Didelot, C.; Morey, L.; Van Eynde, A.; Bernard, D.; Vanderwinden, J.M.; et al. The polycomb group protein ezh2 directly controls DNA methylation. Nature 2006, 439, 871-874. [CrossRef]

188. Wise, L.A.; Radin, R.G.; Palmer, J.R.; Kumanyika, S.K.; Boggs, D.A.; Rosenberg, L. Intake of fruit, vegetables, and carotenoids in relation to risk of uterine leiomyomata. Am. J. Clin. Nutr. 2011, 94, 1620-1631. [CrossRef]

189. Valko, M.; Leibfritz, D.; Moncol, J.; Cronin, M.T.; Mazur, M.; Telser, J. Free radicals and antioxidants in normal physiological functions and human disease. Int. J. Biochem. Cell Biol. 2007, 39, 44-84. [CrossRef]

190. Valko, M.; Rhodes, C.J.; Moncol, J.; Izakovic, M.; Mazur, M. Free radicals, metals and antioxidants in oxidative stress-induced cancer. Chem. Biol. Interact. 2006, 160, 1-40. [CrossRef]

191. Gajowik, A.; Dobrzynska, M.M. The evaluation of protective effect of lycopene against genotoxic influence of X-irradiation in human blood lymphocytes. Radiat. Environ. Biophys. 2017, 56, 413-422. [CrossRef]

192. Gajowik, A.; Dobrzynska, M.M. Lycopene - antioxidant with radioprotective and anticancer properties. A review. Roczniki Państwowego Zakładu Higieny 2014, 65, 263-271.

193. Srinivasan, M.; Devipriya, N.; Kalpana, K.B.; Menon, V.P. Lycopene: An antioxidant and radioprotector against gamma-radiation-induced cellular damages in cultured human lymphocytes. Toxicology 2009, 262, 43-49. [CrossRef] [PubMed]

194. Torbergsen, A.C.; Collins, A.R. Recovery of human lymphocytes from oxidative DNA damage; the apparent enhancement of DNA repair by carotenoids is probably simply an antioxidant effect. Eur. J. Nutr. 2000, 39, 80-85. [CrossRef] [PubMed]

195. Sun, H.; Valdivia, L.A.; Subbotin, V.; Aitouche, A.; Fung, J.J.; Starzl, T.E.; Rao, A.S. Improved surgical technique for the establishment of a murine model of aortic transplantation. Microsurgery 1998, 18, 368-371. [CrossRef]

196. Aydemir, G.; Kasiri, Y.; Birta, E.; Beke, G.; Garcia, A.L.; Bartok, E.M.; Ruhl, R. Lycopene-derived bioactive retinoic acid receptors/retinoid-X receptors-activating metabolites may be relevant for lycopene's anti-cancer potential. Mol. Nutr. Food Res. 2013, 57, 739-747. [CrossRef] [PubMed]

197. Sharoni, Y.; Linnewiel-Hermoni, K.; Zango, G.; Khanin, M.; Salman, H.; Veprik, A.; Danilenko, M.; Levy, J. The role of lycopene and its derivatives in the regulation of transcription systems: Implications for cancer prevention. Am. J. Clin. Nutr. 2012, 96, 1173S-1178S. [CrossRef]

198. Tanaka, T.; Shnimizu, M.; Moriwaki, H. Cancer chemoprevention by carotenoids. Molecules 2012, 17, 3202-3242. [CrossRef]

199. Cho, K.S.; Shin, M.; Kim, S.; Lee, S.B. Recent advances in studies on the therapeutic potential of dietary carotenoids in neurodegenerative diseases. Oxid Med. Cell Longev. 2018, 2018, 4120458. [CrossRef]

200. Terry, K.L.; Missmer, S.A.; Hankinson, S.E.; Willett, W.C.; De Vivo, I. Lycopene and other carotenoid intake in relation to risk of uterine leiomyomata. Am. J. Obstet. Gynecol. 2008, 198, 37.e1-37.e8. [CrossRef]

201. Heber, D.; Lu, Q.Y. Overview of mechanisms of action of lycopene. Exp. Biol. Med. (Maywood) 2002, 227, 920-923. [CrossRef]

202. Rao, A.V.; Rao, L.G. Carotenoids and human health. Pharmacol. Res. 2007, 55, 207-216. [CrossRef]

203. Sahin, K.; Ozercan, R.; Onderci, M.; Sahin, N.; Gursu, M.F.; Khachik, F.; Sarkar, F.H.; Munkarah, A.; Ali-Fehmi, R.; Kmak, D.; et al. Lycopene supplementation prevents the development of spontaneous smooth muscle tumors of the oviduct in Japanese Quail. Nutr. Cancer 2004, 50, 181-189. [CrossRef] [PubMed] 
204. Sahin, K.; Ozercan, R.; Onderci, M.; Sahin, N.; Khachik, F.; Seren, S.; Kucuk, O. Dietary tomato powder supplementation in the prevention of leiomyoma of the oviduct in the japanese quail. Nutr. Cancer 2007, 59, 70-75. [CrossRef] [PubMed]

205. Beecher, G.R. Nutrient content of tomatoes and tomato products. Proc. Soc. Exp. Biol. Med. 1998, 218, 98-100. [CrossRef] [PubMed]

206. Abushita, A.A.; Daood, H.G.; Biacs, P.A. Change in carotenoids and antioxidant vitamins in tomato as a function of varietal and technological factors. J. Agric. Food Chem. 2000, 48, 2075-2081. [CrossRef]

207. Hwang, E.S.; Bowen, P.E. Can the consumption of tomatoes or lycopene reduce cancer risk? Integr. Cancer Ther. 2002, 1, 121-132. [CrossRef]

208. Bicsak, T.A.; Harper, E. Purification of nonspecific protease-free collagenase from clostridium histolyticum. Anal. Biochem. 1985, 145, 286-291. [CrossRef]

209. Brunengraber, L.N.; Jayes, F.L.; Leppert, P.C. Injectable Clostridium histolyticum collagenase as a potential treatment for uterine fibroids. Reprod. Sci. 2014, 21, 1452-1459. [CrossRef]

210. Jayes, F.L.; Liu, B.; Moutos, F.T.; Kuchibhatla, M.; Guilak, F.; Leppert, P.C. Loss of stiffness in collagen-rich uterine fibroids after digestion with purified collagenase clostridium histolyticum. Am. J. Obstet. Gynecol. 2016, 215, 596.e591-596.e598. [CrossRef]

211. Singh, B.; Sims, H.; Truehart, I.; Simpson, K.; Wang, K.; Patzkowsky, K.; Wegman, T.; Soma, J.M.; Dixon, R.; Jayes, F.; et al. Results of a phase 1 clinical trial to assess safety and tolerability of injectable collagenase in women with symptomatic uterine fibroids. In Meeting: The Basic Science of Uterine Fibroids; NC, 27701. 28/FEB/2020; National Institute of Environmental Health Sciences: Research Triangle Park, CA, USA.

212. Rein, M.J.; Renouf, M.; Cruz-Hernandez, C.; Actis-Goretta, L.; Thakkar, S.K.; da Silva Pinto, M. Bioavailability of bioactive food compounds: A challenging journey to bioefficacy. Br. J. Clin. Pharmacol. 2013, 75, 588-602. [CrossRef]

213. Borel, P.; Caillaud, D.; Cano, N.J. Vitamin D bioavailability: State of the art. Crit. Rev. Food Sci. Nutr. 2015, 55, 1193-1205. [CrossRef]

214. Dube, A.; Nicolazzo, J.A.; Larson, I. Chitosan nanoparticles enhance the intestinal absorption of the green tea catechins (+)-catechin and (-)-epigallocatechin gallate. Eur. J. Pharm. Sci. 2010, 41, 219-225. [CrossRef]

215. Granja, A.; Neves, A.R.; Sousa, C.T.; Pinheiro, M.; Reis, S. EGCG intestinal absorption and oral bioavailability enhancement using folic acid-functionalized nanostructured lipid carriers. Heliyon 2019, 5, e02020. [CrossRef]

216. Kunnumakkara, A.B.; Harsha, C.; Banik, K.; Vikkurthi, R.; Sailo, B.L.; Bordoloi, D.; Gupta, S.C.; Aggarwal, B.B. Is curcumin bioavailability a problem in humans: Lessons from clinical trials. Expert Opin. Drug Metab. Toxicol. 2019, 15, 705-733. [CrossRef] [PubMed]

217. Jamwal, R. Bioavailable curcumin formulations: A review of pharmacokinetic studies in healthy volunteers. J. Integr. Med. 2018, 16, 367-374. [CrossRef] [PubMed]

218. Chimento, A.; De Amicis, F.; Sirianni, R.; Sinicropi, M.S.; Puoci, F.; Casaburi, I.; Saturnino, C.; Pezzi, V. Progress to improve oral bioavailability and beneficial effects of resveratrol. Int. J. Mol. Sci. 2019, 20. [CrossRef] [PubMed]

219. Baenas, N.; Suarez-Martinez, C.; Garcia-Viguera, C.; Moreno, D.A. Bioavailability and new biomarkers of cruciferous sprouts consumption. Food Res. Int. 2017, 100, 497-503. [CrossRef] [PubMed]

220. Boots, A.W.; Haenen, G.R.; Bast, A. Health effects of quercetin: From antioxidant to nutraceutical. Eur. J. Pharmacol. 2008, 585, 325-337. [CrossRef]

221. Petyaev, I.M. Lycopene deficiency in ageing and cardiovascular disease. Oxid. Med. Cell. Longev. 2016, 2016, 3218605. [CrossRef]

222. Sies, H.; Stahl, W. Lycopene: Antioxidant and biological effects and its bioavailability in the human. Proc. Soc. Exp. Biol. Med. 1998, 218, 121-124. [CrossRef]

223. Newman, D.J.; Cragg, G.M. Natural products as sources of new drugs over the 30 years from 1981 to 2010. J. Nat. Prod. 2012, 75, 311-335. [CrossRef]

224. Islam, M.S.; Akhtar, M.M.; Ciavattini, A.; Giannubilo, S.R.; Protic, O.; Janjusevic, M.; Procopio, A.D.; Segars, J.H.; Castellucci, M.; Ciarmela, P. Use of dietary phytochemicals to target inflammation, fibrosis, proliferation, and angiogenesis in uterine tissues: Promising options for prevention and treatment of uterine fibroids? Mol. Nutr. Food Res. 2014, 58, 1667-1684. [CrossRef] [PubMed] 
225. Clarke, T.C.; Black, L.I.; Stussman, B.J.; Barnes, P.M.; Nahin, R.L. Trends in the Use of Complementary Health Approaches Among Adults: United States, 2002-2012. In National Health Statistics Reports; No. 79; National Center for Health Statistics: Hyattsville, MD, USA, 2015.

226. Lozinski, T.; Filipowska, J.; Gurynowicz, G.; Zgliczynska, M.; Kluz, T.; Jedra, R.; Skowyra, A.; Ciebiera, M. The effect of high-intensity focused ultrasound guided by magnetic resonance therapy on obstetrical outcomes in patients with uterine fibroids - experiences from the main polish center and a review of current data. Int. J. Hyperthermia 2019, 36, 582-590. [CrossRef] [PubMed]

227. Marsh, E.E.; Ekpo, G.E.; Cardozo, E.R.; Brocks, M.; Dune, T.; Cohen, L.S. Racial differences in fibroid prevalence and ultrasound findings in asymptomatic young women (18-30 years old): A pilot study. Fertil. Steril. 2013, 99, 1951-1957. [CrossRef] [PubMed]

228. American College of Obstetricians and Gynecologists (ACOG). Vitamin D: Screening and supplementation during pregnancy. Committee Opinion No. 495. Obstet. Gynecol. 2011, 118, 197-198.

229. Rusinska, A.; Pludowski, P.; Walczak, M.; Borszewska-Kornacka, M.K.; Bossowski, A.; Chlebna-Sokol, D.; Czech-Kowalska, J.; Dobrzanska, A.; Franek, E.; Helwich, E.; et al. Vitamin D supplementation guidelines for general population and groups at risk of vitamin D deficiency in poland-recommendations of the Polish Society of Pediatric Endocrinology and Diabetes and the expert panel with participation of national specialist consultants and representatives of scientific societies-2018 update. Front. Endocrinol. (Lausanne) 2018, 9, 246. [CrossRef]

230. American College of Obstetricians and Gynecologists (ACOG). Moderate caffeine consumption during pregnancy. Committee Opinion No. 462. Obstet. Gynecol. 2010, 116, 467-468.

231. Tenore, G.C.; Daglia, M.; Ciampaglia, R.; Novellino, E. Exploring the nutraceutical potential of polyphenols from black, green and white tea infusions - an overview. Curr. Pharm. Biotechnol. 2015, 16, 265-271. [CrossRef]

232. Zhong, J.; Xu, C.; Reece, E.A.; Yang, P. The green tea polyphenol EGCG alleviates maternal diabetes-induced neural tube defects by inhibiting DNA hypermethylation. Am. J. Obstet. Gynecol. 2016, 215, 368.e1-368.e10. [CrossRef]

233. Wu, X.K.; Wang, Y.Y.; Liu, J.P.; Liang, R.N.; Xue, H.Y.; Ma, H.X.; Shao, X.G.; Ng, E.H.; Reproductive Developmental Network in Chinese, M. Randomized controlled trial of letrozole, berberine, or a combination for infertility in the polycystic ovary syndrome. Fertil. Steril. 2016, 106, 757-765. [CrossRef]

234. Spinozzi, S.; Colliva, C.; Camborata, C.; Roberti, M.; Ianni, C.; Neri, F.; Calvarese, C.; Lisotti, A.; Mazzella, G.; Roda, A. Berberine and its metabolites: Relationship between physicochemical properties and plasma levels after administration to human subjects. J. Nat. Prod. 2014, 77, 766-772. [CrossRef]

235. National Institutes of Health (NIH). National Center for Complementary and Integrative Health. Goldenseal; 2018. Available online: http://nccih.nih.gov/health/goldenseal (accessed on 11 May 2020).

236. Li, L.; Li, C.; Pan, P.; Chen, X.; Wu, X.; Ng, E.H.; Yang, D. A single arm pilot study of effects of berberine on the menstrual pattern, ovulation rate, hormonal and metabolic profiles in anovulatory chinese women with polycystic ovary syndrome. PLoS ONE 2015, 10, e0144072. [CrossRef] [PubMed]

237. Chiaffarino, F.; Parazzini, F.; La Vecchia, C.; Chatenoud, L.; Di Cintio, E.; Marsico, S. Diet and uterine myomas. Obstet. Gynecol. 1999, 94, 395-398. [CrossRef] [PubMed]

238. Chen, N.N.; Han, M.; Yang, H.; Yang, G.Y.; Wang, Y.Y.; Wu, X.K.; Liu, J.P. Chinese herbal medicine guizhi fuling formula for treatment of uterine fibroids: A systematic review of randomised clinical trials. BMC Complement. Altern. Med. 2014, 14, 2. [CrossRef] [PubMed]

239. Chwalisz, K.; Taylor, H. Current and emerging medical treatments for uterine fibroids. Semin. Reprod. Med. 2017, 35, 510-522. [CrossRef] [PubMed]

240. Kasinski, A.L.; Du, Y.; Thomas, S.L.; Zhao, J.; Sun, S.Y.; Khuri, F.R.; Wang, C.Y.; Shoji, M.; Sun, A.; Snyder, J.P.; et al. Inhibition of IkappaB kinase-nuclear factor-kappab signaling pathway by 3,5-bis(2-flurobenzylidene) piperidin-4-one (EF24), a novel monoketone analog of curcumin. Mol. Pharmacol. 2008, 74, 654-661. [CrossRef]

(C) 2020 by the authors. Licensee MDPI, Basel, Switzerland. This article is an open access article distributed under the terms and conditions of the Creative Commons Attribution (CC BY) license (http://creativecommons.org/licenses/by/4.0/). 